\title{
Applications of Yeast Flocculation in Biotechnological Processes
}

\author{
Lucília Domingues, António A. Vicente, Nelson Lima, and José A. Teixeira* \\ Centro de Engenharia Biológica - IBOF, Universidade do Minho, Campus de Gualtar, 4710-057 Braga, Portugal
}

\begin{abstract}
A review on the main aspects associated with yeast flocculation and its application in biotechnological processes is presented. This subject is addressed following three main aspects - the basics of yeast flocculation, the development of "new" flocculating yeast strains and bioreactor development. In what concerns the basics of yeast flocculation, the state of the art on the most relevant aspects of mechanism, physiology and genetics of yeast flocculation is reported. The construction of flocculating yeast strains includes not only the recombinant constitutive flocculent brewer's yeast, but also recombinant flocculent yeast for lactose metabolisation and ethanol production. Furthermore, recent work on the heterologous $\beta$-galactosidase production using a recombinant flocculent Saccharomyces cerevisiae is considered. As bioreactors using flocculating yeast cells have particular properties, mainly associated with a high solid phase hold-up, a section dedicated to its operation is presented. Aspects such as bioreactor productivity and culture stability as well as bioreactor hydrodynamics and mass transfer properties of flocculating cell cultures are considered. Finally, the paper concludes describing some of the applications of high cell density flocculation bioreactors and discussing potential new uses of these systems.
\end{abstract}

Keywords: recombinant yeast, flocculation, airlift bioreactor, heterologous protein production, fermentation

\section{INTRODUCTION}

Yeasts are, without any doubt, the most exploited microorganisms known and $S$. cerevisiae strains, the most representative yeast genus, are involved in the production of some important products consumed by human race such as bread, wine, beer, and distilled drinks. Fuel ethanol production using yeast is also of relevance.

Productivity increase is one of the main goals in any biotechnological process. This can be achieved in several ways:

- using new or modified strains;

- developing new bioreactors and optimising the operation strategies;

- improving the efficiency of separation processes;

- using efficient control systems.

Techniques that make use of cell immobilisation are clearly a very promising alternative as a way of improving biotechnological process productivity. In fact, the use of these systems presents several advantages:

- high cell densities per unit bioreactor volume, resulting in very high fermentation rates;

- reuse of the same biocatalyst (cells) for extended periods of time due to constant cell regeneration;

*Corresponding author

Tel: +351-253-604400 Fax: +351-253-678986

e-mail: jate1xeira@deb.uminho.pt
- possibility of operation beyond the washout rate;

- easy separation of biocatalyst (cells) from the liquid phase;

- minimised risk of contamination;

- smaller bioreactor volumes, reducing capital costs.

Among the several available immobilisation techniques, the use of flocculating microorganisms, due to its simplicity and low cost, is very attractive - no complex mechanical devices are needed as well as no support. This is a clear advantage over other immobilisation techniques since it is well known that support represents a major cost in immobilisation procedures.

However, at industrial scale, systems using flocculating yeast cells have been only utilised in the latter phase of primary beer fermentation to separate biomass from the fermented broth. No continuous fermentation systems using flocculating yeast cells have been implemented industrially, their implementation requiring a complete comprehension of the mechanisms involved in yeast flocculation and its control, in order to develop yeast strains with the adequate flocculation ability. They must be coupled with the appropriate bioreactor design and operating conditions.

\section{BASICS OF YEAST FLOCCULATION}

\section{Yeast Flocculation Mechanism}

Yeast flocculation is defined as the non-sexual cell ag- 
gregation (Fig. 1), which allows cell separation from the fermented broth. It can be inhibited by EDTA or sugars, and restored by $\mathrm{Ca}^{2+}$ ions. The observation of this phenomenon dates back to Pasteur scientific notes and it has been widely used in the brewing industry, probably for millennia. However, its mechanism has raised much controversy in this century. Early reports included sexual agglutination and chain formation in yeast flocculation [1]. Nevertheless, the mechanism involved in these three types of cell adhesion is different. In sexual agglutination, complementary haploid strains, $\alpha$ and a in case of Saccharomyces cerevisiae, exchange small peptide pheromones, $\alpha$ - and a-factors that cause a number of physiological changes. After these modifications, cells aggregate before nucleus-fusion to form diploids. Adhesion between cells is by protein/protein bonding between $\alpha$ - and a-agglutinins anchored in the complementary cell walls. Chain formation occurs when the bud cell fails to separate from the mother cell during yeast growth, resulting in chain formation as both the mother and daughter cells continue to form new buds. In this case the cells are physically joined at their cell walls. Chain formation is known to occur in S. cerevisiae strains due to nutrient deprivation or yeast strain $\mathrm{mu}-$ tation. Mill [2] reported formally the first proposed theory for yeast flocculation mechanism besides the colloidal theory based on surface charge neutralization (see for review [3]) that would not hold for $\mathrm{Ca}^{2+}$ specificity. Mill's theory stated that flocculated cells are linked by salt bridges with $\mathrm{Ca}^{2+}$ ions joining two carboxyl, phosphate and/or sulphate groups at the surface of two cells; the structures thus formed are stabilised by hydrogen bonds between complementary carbohydrate hydroxyl groups at the cell wall surface. The observed effect of $\mathrm{pH}$ on flocculation suggested carboxyl groups as the most likely combining sites [2]. Both carboxyl and phosphate groups can be considered as functional groups of amino acid side chains of the proteins on the cell walls, corroborating the loss of flocculation observed after treatment with proteases and proteindenaturing agents [4-11]. However, the calcium bridge hypothesis could not explain the observed inhibition of flocculation by sugars. Amri and collaborators [12] after a study on flocculent cell walls concluded that carboxyl groups were involved in flocculation but they also stated that the phenomenon of flocculation seemed more complex than the simple formation of a $\mathrm{Ca}^{2+}$ bridge, and that the involvement of "lectin like" components easily removed from the cell walls, should not be rejected. In 1982, Miki and collaborators [13] presented evidence for a new flocculation model stating that flocculation interactions may be mediated by a specific cell surface recognition mechanism, involving lectin-like binding of surface proteins to polysaccharides on adjacent cells. This model corroborates the calcium ions stereospecificity found in flocculation phenomenon and the sugar involvement [14] not explained by the bridge theory. In the lectin hypothesis the role of $\mathrm{Ca}^{2+}$ ions would be to maintain lectins in an active conformation. According to the lectin-like hypothesis, floc-

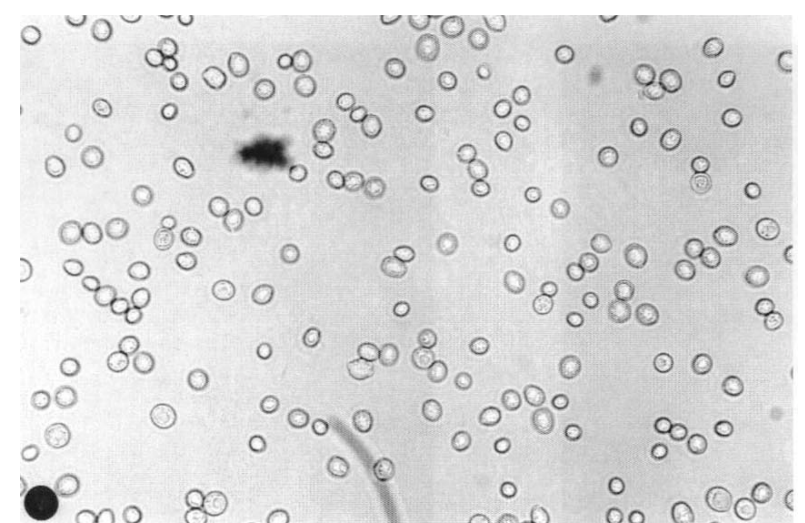

(a)

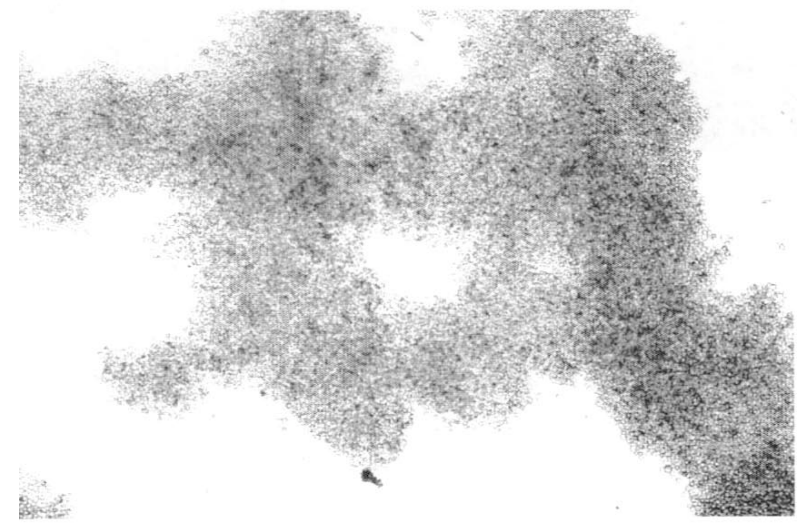

(b)

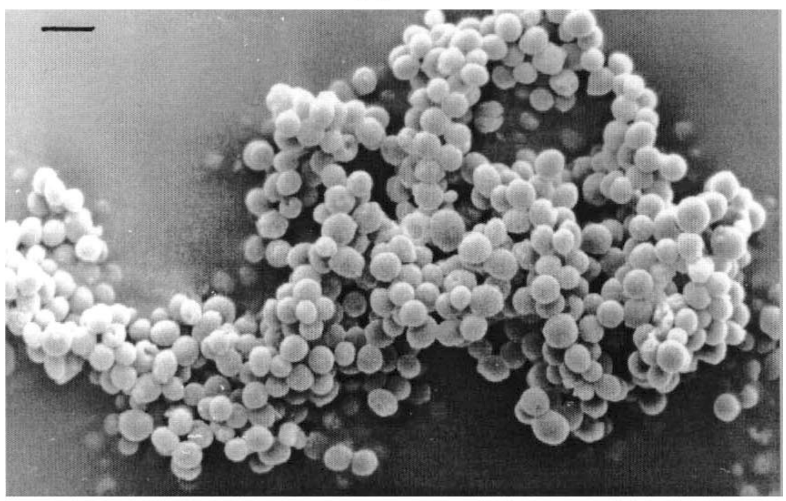

(c)

Fig. 1. Flocculent and non-flocculent Saccharomyces cerevi-siae cells photographs obtained by: (a) Non-flocculent cells (optical bright field microscopy 400X), (b) Flocculent cells (optical bright field microscopy 100X), (c) Flocculent cells (SEM; bar corresponds to $10 \mu \mathrm{m}$ ).

culation is mediated by the interaction between two distinct components of the same cell surface. The receptors, found both on flocculent and non-flocculent cells, are most probably $\alpha$-branched mannans, as suggested by 1) mannose specific sugar inhibition [14] in $S$. cerevisiae, 2) lack of coflocculation with yeast known to lack mannan in its cell wall, such as Schizosaccharomyces pombe [13] and 3) mannan blocking and chemical modification experiments $[13,15]$. The presence of carbohy- 
drate receptors was confirmed using known mnn mutants [16], which varied in wall mannan structure and showed that flocculation receptors were the outer chain $\mathrm{N}$-linked mannan side branches, two or three mannose (Man) residues in length. For Kluyveromyces lactis, the structure of the phosphopeptidomannans from flocculent and non-flocculent yeast demonstrated that flocculent strains have a non-reducing terminal $\operatorname{Man}(\alpha 1,3)$ Man sequence [17], unlike non-flocculent strains. The receptors may be specifically bound to a lectin-like cognor, active only on the surfaces of flocculent yeasts.

Due to the protein lectin nature, attempts to isolate proteins unique to flocculation have been going on for many years. A number of possible protein bands on SDS gels have been found, ranging in size from 13 to 67 $\mathrm{kDa}$ [18] and antibodies against proteins on flocculent cells have been raised [19]. The presence of a $37 \mathrm{kDa}$ protein in extracts of flocculent cultures was reported for $S$. cerevisiae strains [20], K. marxianus strains [11, 21,22], and flocculent Hansenula anomala strains [23]. A polypeptide of $13 \mathrm{kDa}$ was also identified in alkaline cell extracts of flocculent $S$. cerevisae $[24,25]$, as well as a 25 $\mathrm{kDa}$ protein [26]. In the K. marxianus case, the involvement of p37 in flocculation was recently supported by the fact that a $K$. marxianus mutant, deficient in the synthesis of p37, was no longer able to flocculate [27]. The isolation of surface lectin-like proteins from flocculent cells has been reported [28-32].

After careful examination of the physiology of a large number of laboratory and brewery flocculent strains, Stratford presented evidence of two groupings of yeast strains suggesting two different lectin mechanisms $[33,34]$. One group was termed Flo1 phenotype since it contained all strains bearing FLO1 gene and also all other genes known to be involved in flocculation. This lectin mechanism was manno-specific. The other group was named the NewFlo phenotype, involving a large majority of brewery ale strains with unknown genotype, showing a manno- and gluco-specific lectin. The two phenotypes were distinguished by sugar, salt and low $\mathrm{pH}$ inhibitions, protease sensitivity, and selective expression of flocculation.

Although mainly studied in brewery yeasts, flocculation is spread over other yeast genera and bacteria. The mechanism of flocculation in other yeasts seems to follow the lectin theory (as supported by the data on isolation of proteins involved in flocculation) even though the lectin specificity could be different. For instance, galactose and its derivatives inhibit flocculation of Kluyveromyces bulgaricus and Kluyveromyces lactis species, as the interaction involves a galactose-specific lectin $[28,29,35,36]$. Also a study on the flocculation mechanism of a $K$. marxianus strain, as compared with a $S$. cerevisiae strain [37] suggested that the structure and/or spatial arrangement of the cell wall groups involved in flocculation were not the same in $K$. marxianus and $S$. cerevisiae, being nevertheless compatible with the lectin hypothesis.

The phenomenon of bacterial-induced yeast floccula- tion [38] seems to involve lectins from bacterial walls or, alternatively, the high molecular weight polysaccharides could be bridging between lectins on flocculent cells.

The adhesion of Candida species to cells of the host organism and many bacterial infections are mediated by surface lectins [39]. Curiously, lectins of infectious microorganisms are associated with surface structures termed fimbriae; similar structures have also been associated with flocculent yeast cells $[40,41]$.

Considering the accumulated knowledge from flocculation genetics, a slightly modified lectin model was proposed [42], gaining support from subsequent experimental data. These authors proposed that flocculins might be (functioning as) lectins or at least have the sugar-binding properties associated with lectins. The major difference with Miki's model is that flocculins, being cell-associated glycoproteins, directly bind the mannoproteins of neighbouring cells. The flocculin, therefore, fulfils the same role as the two proteins in the Miki model, combining anchoring and binding properties. These authors also stated that the flocculation mechanism is basically the same for the NewFlo and Flo1 flocculation phenotypes, being the differences quantitative rather than qualitative. As a third flocculation phenotype group has been described [43] in which flocculation is mannose-insensitive and independent of $\mathrm{Ca}^{2+}$ ions, in this case a flocculation mechanism different from the NewFlo and Flo1 phenotypes is suggested. The flocculation lectin might correspond to the product of the dominant flocculation genes, such as FLO1 or related genes, which have been known for a long time to play a major role in flocculation (see genetics of flocculation section). The deduced amino acid sequence from the FLO1 gene revealed a serine- and threoninerich protein with the $\mathrm{N}$ - and $\mathrm{C}$-terminal regions that are hydrophobic and contain a potential membranespanning region [44], suggesting that the Flo1 protein is an integral membrane protein and a cell wall component. Further evidence has shown that Flo1 $p$ was a true cell wall mannoprotein $[45,46]$. In agreement with this idea Bony and co-workers [47] showed that the availability of Flo proteins at the cell surface of yeasts is well correlated with the flocculation level, being its distribution at the cell surface dependent on the constraints of cell wall biogenesis. The study of the Flo1 protein indicated that the hydrophobic C-terminus, which is a putative GPI anchoring domain, is necessary for the anchoring of Flo1p in the cell wall [45] and that the Nterminal domain of the protein is responsible for sugar recognition $[45,46]$. Supporting Teunissen and Steensma model [42], Kobayashi et al. [46] found that modification of two regions was required to change the mannose-specific sugar recognition pattern of the Flo1 protein to the mannose/glucose-specific pattern.

While experimental data accumulate elucidating the complex molecular mechanism for yeast flocculation, its role in nature is still unclear. In $K$. marxianus, the protein p37 involved in yeast flocculation can be induced by two different methods involving stresscontinuous fermentation [48] or thermal stress [22]. In 
S. cerevisiae, induction of flocculation by nutrient limitation has been considered [49]. More recently, it has been reported the involvement of some flocculation genes in filamentous growth [50-52], which are induced by nitrogen starvation. All in all, it seems that flocculation may be a defence mechanism adopted by some yeast strains, in response to adverse factors to the yeast cell. The floc formation may generate nutritionally rich microenvironments by selective lysis [53]. Further work is needed to determine the role of flocculation in nature.

\section{Physiology of Yeast Flocculation}

In 1958, Eddy and Phil [1] pointed out that despite the fact that the particular properties involved in flocculation were sometimes viewed as of an extremely variable nature, there were some that unless exactly controlled might lead to a false impression of variability. These properties include medium chemical composition, in particular salt and sugar content, $\mathrm{pH}$, temperature, aeration, and agitation.

Flocculation development is influenced by medium salt content. Although some controversial data is found in literature concerning other cations, it is widely accepted the "activation" of flocculation by calcium ions. The presence of calcium ions is required at a very low concentration - $10^{-8} \mathrm{M}$, according to Taylor and Orton [54] - in order to induce flocculation. The controversial data involving other cations is due to the use of different cation concentrations, different flocculation measurement techniques, different $\mathrm{pH}$ values and strains with different genetical background. For instance, the FLO5 and FLO1 strains showed different patterns for the competing effects of other cations with $\mathrm{Ca}^{2+}[55]$. For low salt concentrations (cations other than $\mathrm{Ca}^{2+}$ ), there is an observed flocculation enhancement, while at high concentrations inhibition by salt is observed. The $\mathrm{Ca}^{2+}$ ion leakage or release from the cell promoted by other cations, namely magnesium ions, is one of the possible reasons for the flocculation induction at low salt concentrations [33]. In fact, Nishihara et al. [6] reported the need of the cation $\mathrm{Mg}^{2+}$, at a minimal concentration of $20 \mu M$, for flocculation to occur. Stewart and Goring [56] reported that $\mathrm{Mg}^{2+}$ and $\mathrm{Mn}^{2+}$ could imitate $\mathrm{Ca}^{2+}$ even though the flocculation intensity was lowered. The same authors reported that low concentrations of sodium and potassium $(1-10 \mathrm{mg} / \mathrm{L})$ also would induce flocculation on the strains studied. Other reasons for the promoting flocculation effect of low salt concentration are the lowering of yeast surface charge and the modifying effect on surface proteins, in a manner similar to that described as "salting in and salting out" for protein solubility [39]. Many salts are reported to cause inhibition of flocculation, depending on the concentration. These include the alkaline-earth metal ions $\mathrm{Sr}^{2+}$ and $\mathrm{Ba}^{2+}[10,33,54,55], \mathrm{Na}^{+}[2,10,33,40,54], \mathrm{K}^{+}$ $[33,40,57]$, citrate ions [33], $\mathrm{Ca}^{2+}[58], \mathrm{Mg}^{2+}[58], \mathrm{Mn}^{2+}$ [55], Cs salts [58], $\mathrm{Al}^{3+}$ [55], $\mathrm{La}^{3+}$ [55] and $\mathrm{Li}^{+}$[33].

Another important constituent in medium composition is sugar. Different sugars cause different effects on flocculation. Kihn et al. [59] reported that while one brewer's yeast strain (S. cerevisiae MUCL28323, top fermenting strain) was inhibited by mannose and other two (S. uvarum MUCL28235 and M259, bottom fermenting strains) were inhibited by mannose, maltose and glucose, there was no observable sugar inhibition in the top fermenting strains S. cerevisiae MUCL28733 and MUCL28734. Stratford and Assinder [34] grouped the flocculent yeast strains in two groups: those strains showing mannose sensitive flocculation (Flo1 phenotype), and those showing flocculation inhibition by several sugars (NewFlo phenotype). Later, Masy et al. [43] reported the existence of a third group, showing no flocculation inhibition by mannose or glucose. The sugar inhibition of flocculation is therefore strain dependent, having a direct effect rather than acting metabolically [34]. In Schizosaccharomyces pombe the flocculation inhibition by the sugar galactose and to a less extent, by glucose, has been reported, while for the sugar fructose and mannose, and for L(-) malic acid no flocculation inhibition was observed [60].

$\mathrm{pH}$ was first considered not to be a determinant factor of flocculation, being its effect mainly due to alteration of cell surface charge [39]. However, yeast flocculation is associated with different phenotypes, like the already mentioned Flo1 and NewFlo, which differ also in their $\mathrm{pH}$ tolerance. The Flo1 phenotype shows a very broad tolerance, exhibiting flocculation between $\mathrm{pH} 1.5$ and $10[39,61]$. The NewFlo strains exhibited two distinct phenotypes: some flocculated over a broad range while others within a narrow $\mathrm{pH}$ range [61]. For the latter strains, $\mathrm{pH}$ is a determinant factor for flocculation to occur. Stratford [61] has shown that many brewing strains do not flocculate in laboratory culture media, because their initial $\mathrm{pH}$ and buffering capacity do not allow for the $\mathrm{pH}$ range within which these yeasts flocculate. Once the $\mathrm{pH}$ was corrected the brewing yeast strains were able to flocculate in laboratory culture media. With these strains, a simple change of $\mathrm{pH}$ at any desired time during fermentation, allows for cell separation from the medium [61]. Also, Yang and Choi [62] found for a $S$. cerevisiae strain that flocculation was induced by $\mathrm{pH}$ upshift.

Temperature may influence flocculation development and expression. There is an apparent contradiction in the literature; some authors noted deflocculation with increasing temperature while others noted an increase in flocculation with increasing temperature. This discrepancy may be attributed to differences in the response of ale and lager strains (reviewed in [63]). Nevertheless, it was shown that temperature did not inhibit cell-cell interactions, but it seemed to induce or repress the formation of a cell wall component involved in flocculation. As the yeast secretory pathway is prone to temperature-sensitive mutations [39], the temperature may alter the availability of the Flo protein rather than having a direct effect on flocculation. For Kluyveromyces marxianus strain, flocculation can be induced by a temperature upshift [22]. Once more, this effect was related to an increase in the synthesis and subsequent accumu- 
lation of a protein in the cell wall.

The aeration effect on flocculation seems to be related with the mitochondrial function. The presence of respiratory inhibitors represses the flocculation induction [6] and the respiratory-deficient mutants show different flocculation behaviour when compared to parental strains [20]. The induction of flocculence is repressed by cycloheximide, but not by chloramphenicol. Nishihara et al. [6] conculded that mitochondrial function was more important than synthesis of mitochondrial proteins. As mitochondrion affects the secretion process, the mitochondria effect on flocculation can be also an indirect effect [39]. Another indirect effect considered in flocculation is the oxygen influence by increasing the cell wall hydrophobicity [64], which has been related with flocculation by several authors $[23,49,64-69]$. The combined effect of aeration and glucose concentration has also been studied [70,71], revealing that for extreme aeration conditions $(0.1$ and 5 vvm) the initial glucose concentration was not important while for an intermediate aeration rate of $1 \mathrm{vvm}$, high glucose concentrations (6 to $10 \% \mathrm{w} / \mathrm{v}$ ) increased flocculation [71].

Agitation has two antagonistic effects: enhanced particle collision rate induces flocculation on the one hand, and on the other higher shear forces cause particle breakage [72-74]. An increase in agitation intensity leads to a decrease in floc size $[75,76]$. Being so, gentle agitation gives large flocs while vigorous agitation gives smaller denser flocs that settle more slowly but give a compact sediment [74-76].

The environmental properties mentioned above may be controlled allowing not only for a better understanding of the phenomenon but also for its control. Nevertheless, the strain variability must be taken into account, as this is one of the reasons for most of the controversy found in literature data concerning flocculation.

\section{Genetics of Yeast Flocculation}

Due to the relevance of flocculation on the brewing industry, much effort has been given to elucidate the genetic and environmental control of flocculation. The control of flocculation is sought not only to be applicable in the brewing industry, but also to make practical application of the phenomenon in biotechnology.

During the early 1950's Gilliland [77] and Thorne [78] independently carried out a study on the yeast flocculation genetics, establishing the existence of flocculation genes by genetic crosses. Until the 70's, flocculation was recognized to be dominant and to be under the control of multiple gene pairs [79]. Despite the difficulties concerning tetrad analysis of brewing strains due to their low spore viability, in the 70's several genes conferring flocculation were recognized. Lewis and Johnston identified the dominant flocculation genes, FLO1 [80] and FLO2 [81] and the recessive gene flo3 [82]. Stewart and collaborators identified the dominant gene FLO4, located in chromosome I $[20,83]$. Further studies indicated that FLO1, FLO2 and FLO4 are in fact allelic [84]. The identification of chromosomal genes responsible for flocculation lead to some enthusiasm, but further studies revealed that flocculation is not a straightforward molecular mechanism. According to our present knowledge, at least 35 genes were identified as to be involved in flocculation (reviewed in [42]). A gene family consisting of two dominant genes discovered by classical genetics, FLO1 and FLO5, and the two dominant genes, FLO9 and FLO10, identified on the basis of sequence homology to FLO1 [42] encode for proteins with a high degree of homology. The dominant FLO11 gene, with a high degree of homology with the STA1 gene, is more distantly related to this gene family, with a similarity of $37 \%$ to the product of the FLO1 gene [85]. The FLO9 gene product is $96 \%$ similar to the FLO1 product; FLO10 product is 58\%, while the FLO1 and FLO5 gene products are $96 \%$ similar [42]. Recently, a new FLO gene sharing no homology with the FLO1 gene has been described and mapped on the right arm of chromosome XII [86]. The new gene confers a strong flocculation phenotype, comparable in all aspects to that induced by FLO1, and was named FLO2 [86]. The transformation of a flo1 mutant with pSV1 vector carrying FLO2 gene resulted in a flocculation phenotype. The authors [86] suggested that FLO2 could be a structural gene, similar in function (but not in sequence) to FLO1 that would normally be silent in all $S$. cerevisiae strains but otherwise active when cloned in a plasmid. From Southern analysis and data from the Saccharomyces genome database it has been shown that FLO2 activates silent FLO genes (other than FLO1) in nonflocculating strains [86]. Further work is required to elucidate the $\mathrm{FLO} 2$ function. Some controversial data has involved the dominant FLO8 gene [87-93]. Finally, Kobayashi and collaborators [94] cloned the FLO8 gene and their results suggested that the FLO8 gene mediates flocculation via transcriptional activation of the FLO1 gene. These authors also suggest that the FLO8 gene is located on chromosome $\mathrm{V}$ and not VIII as reported by Yamashita and Fukui [88]. The FLO5 gene has been first mapped on chromosome I by cytoduction [95] and its localization was confirmed later by cloning the FLO5 gene [96]. The semi-dominant and recessive genes flo3, flob and flo 7 are probably allelic to one of the flocculation genes FLO1, FLO5, FLO9 and FLO10 [42]. Besides the four dominant genes (FLO1, FLO5, FLO9 and FLO10), the transcriptional regulatory gene FLO8, the new FLO2 gene, the semi-dominant flo 3 and the recessive $f l 06$ and $f l 07$, mutations in several genes have been found to cause flocculation (for details see review in [42]). Some of these mutations involve regulatory genes, like the TUP1 and SSN6 genes, others mitochondrial genes like the oli1 and oxi2 [97], or genes involved in cell wall biosynthesis. The expression in yeast of heterologous genes like the human Ha-ras and the viral tax gene caused yeast flocculation. The mechanism behind the flocculation induction in such different situations is far from being understood. More recently, the overexpression of the GTS1 gene has been reported to result in 
constitutive flocculation [98], even when expressed in a yeast strain lacking the FLO1 gene, suggesting that the flocculation mediated by these two genes is unlinked. Overexpression of GTS1 results in an increase of thermotolerance (broadening the tempera-ture growth optimum and increasing lethal heat shock resistance) and in a change in the cell wall long-chain fatty acids profile (leading to a reduced cell surface charge and increased hydrophobicity). Further work is needed to elucidate the mechanism underlying the constitutive flocculation effect of GTS1 gene overexpression.

As mentioned before, the four dominant structural genes, FLO1, FLO5, FLO9 and FLO10, encode for highly homologous proteins. These proteins are anchored in the cell wall with the C-terminus, while the $\mathrm{N}$-terminal sugar-binding part is protruding in the medium [42,4447]. All strains containing these FLO genes belong to the Flo1 phenotype [34]. Until recently, nothing was known about the genetics of the NewFlo phenotype flocculation. Kobayashi and collaborators [46], have isolated a new FLO1 homologue, Lg-FLO1, from a bottom fermenting yeast strain belonging to the NewFlo phenotype, and replaced the FLO1 gene in a Flo1 phenotype strain with the Lg-FLO1 gene. They showed that the FLO1 and Lg-FLO1 genes encode a mannose-specific and mannose/glucose-specific lectin-like protein, respectively, identifying the region responsible for sugar recognition. These data support the slightly modified lectin model proposed by Teunissen and Steensma [42], being the flocculation mechanism basically the same for both the NewFlo and Flo1 flocculation phenotypes. However, a third group named mannose-insensitive has been described by Masy et al. [43] which is insensitive to mannose and independent of $\mathrm{Ca}^{2+}$ ions. They [43] suggested that flocculation in such strains could be produced by hydrophobic interactions or other specific interactions not involving mannans. It is likely that the flocculation mechanism of these strains is different from the Flo1 and NewFlo mechanism. The GTS1 overexpression could be related to this type of flocculation since an increase in hydrophobicity has been noticed [98]. However, further data are required.

Recently, the overexpression of the Kluyveromyces marxianus GAP1 gene, encoding for the p37 protein, in Saccharomyces cerevisiae, resulted in flocculation of the transformed yeast strain [99]. The transformed strain exhibited a flocculation/deflocculation phenotype very similar to that of K. marxianus. Again, other mechanism rather than the Flo1/NewFlo flocculation mechanism might be present. Interestingly, the cell wall hydrophobicity correlates linearly with the flocculation ability of this strain, being the major determinant in the flocculation ability of $K$. marxianus [68]. It is worth noting that being hydrophobicity a function of cell wall protein and composition [100], the influence of hydrophobicity in flocculation does not rule out the lectin theory.

\section{DEVELOPMENT OF NEW FLOCCULENT}

\section{YEAST STRAINS}

Flocculation is a determinant yeast property in brewing being considered the chief factor in termination of fermentation [39]. If flocculation occurs early, removing suspended yeast, attenuation will cease and result in a hung fermentation containing residual sugar. The control of yeast flocculation is therefore of prime importance to the brewing industry. Moreover, the growing interest in flocculation bioreactors due to their high cell density and high productivity in continuous processes emphasizes the need for controlling yeast flocculation. The flocculent brewery yeasts, which only flocculate in the stationary phase of growth, are unsuitable for use in continuous bioreactors, since single exponentially growing cells would be washed out [39]. The advantages of flocculating systems led to research aiming not only at controlling flocculation, but also at inserting new properties into constitutively flocculent yeast strains for industrial applications.

\section{Transfer of Flocculation Properties to Non- flocculent Yeasts}

In 1980, Barney and collaborators [101] reported the genetic transformation of flocculence in Saccharomyces cerevisiae, without a vector, by the induced uptake of native yeast DNA by spheroplasted, nonflocculent recipients. They demonstrated the cotransformation of the linked ade 1 and FLO1 gene, proving that the transfer of a gene for flocculence (FLO1) to a nonflocculent yeast, results in a new flocculent yeast strain.

Aiming at improving the yield of the batch process in cane molasses fermentation and using a flocculent yeast for a continuous molasses or cane juice fermentation, Figueroa et al. [102] reported the transfer of the flocculation property to the yeast $S$. cerevisiae. This yeast is used as distillery yeast in batch processes in Argentina for ethanol production from sugar cane molasses. Also for the improvement of biotechnological ethanol production, the construction of hybrids between a $S$. cerevisiae saké strain and a laboratory flocculent $S$. cerevisiae NCYC 869 strain (FLO1) by intraspecific protoplast fusion was reported [103]. The new hybrids contained both the fermentation characteristics of industrial $S$. cerevisiae saké strain and flocculence.

While FLO1 gene expression is subjected to matingtype regulation, the expression of the FLOS gene is not affected by the mating-type locus, suggesting the potential usefulness of the FLOS gene in constructing polyploid flocculent strains [104]. The hybrid strains, constructed by sexual mating between a wine/brewer's yeast and a laboratory flocculent yeast strain (FLO5), showed strong flocculation ability [104].

The FLO1 gene has been cloned, sequenced and transformed to both top- and bottom- fermenting nonflocculent yeasts $[25,44,91,105]$. As it was known that stability of the YEp-type plasmid was extremely high in bottom-strains under non-selective condition, the cloning of the FLO1 gene was first performed by a multi- 
copy plasmid [105]. In addition, the multi-copy of the FLO1 gene may relieve the mating-type repression in industrial strains being useful in the construction of flocculent industrial strains [105]. Despite the fact that the modified strains were genetically unstable [105], no substantial difference was found between the trial and control beers. The same gene, FLO1, has been integrated in the genome of a non-flocculent bottom brewing yeast strain, resulting in a stable constitutive expression of the flocculation phenotype [106].

So far, the FLO1 gene has only been expressed constitutively in transformed brewing yeasts. As early flocculence during fermentation should not occur because it significantly slows down the fermentation rate, by appropriate promoter constructions, the flocculation can be induced at a later stage of beer fermentation.

The introduction of flocculation property into wine yeasts (S. cerevisiae) by hybridisation has been reported [107]. More recently, the transfer of the flocculation property to a non-flocculent $S$. cerevisiae by cloning the heterologous gene GAP1 from $K$. marxianus has been reported [99].

For the flocculent yeast strains constructed aiming at continuous biological ethanol production, the constitutive flocculation expression phenotype is desired. In this case, the stability of the flocculation characteristic is the main concern.

\section{Transfer of Relevant Industrial Properties to Flocculent Yeast}

Flocculent yeasts allow for the operation at high cell density, with overall increased productivity. As flocculent cells easily separate from the surrounding medium, its use is attractive even for batch or fed-batch operation (Fig. 2). The continuous operation at high cell density with flocculent cells has the same main advantages of immobilised systems, facilitating the downstream processing and presenting higher overall productivity. In addition, it is economically more attractive as there is no need for the support. Being so, the development of flocculent cells for ethanol production from cheap raw materials or even for protein production is considered to be an attractive bioprocess.

When considering the genetic transformation of flocculent yeast cells, some additional difficulties may be expected, due to its different cell wall structure. It is well known that flocculent yeast cells are more resistant to protoplast formation than non-flocculent yeast cells [108]. Recombinant DNA methods have already been used to introduce several new properties into brewing yeasts such as the ability to degrade carbohydrates, modifications to the processes responsible for beer flavour production, and the already referred changes to yeast flocculation [109]. However, it is worth noting that brewing yeasts flocculate only at the end of fermentation. Thus, they can be genetically modified under a non-flocculent state, which is not the case for constitutively flocculent yeast cells.
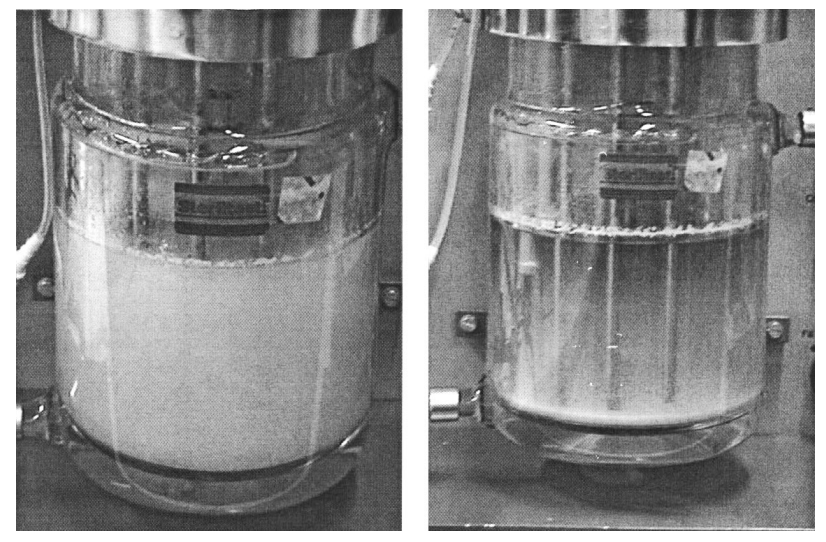

Fig. 2. View of a flocculating yeast cell culture with stirring (150 rpm.) (a) and 45 seconds after stirring was stopped (b).

UV radiation was used to construct ura mutants from a respiratory competent and highly flocculent $S$. cerevisiae NCYC 869 strain [103]. The auxothrophic mutants were selected by growth on minimal medium with glycerol as carbon source, supplemented with uracil and $1 \mathrm{mg} / \mathrm{mL} 5$-FOA. The mutant A3 was selected as it showed the best back mutation frequency $\left(<6.5 \times 10^{-}\right.$ ${ }^{10}$ ) and produced the same degree of flocculation. The A3 mutant was affected in the genes either coding for orotidine-5'-phosphate decarboxylase or for oritidine-5' phosphate pyrophosphorylase. The mutation was confirmed to be ura3 by complementation with a plasmid containing the URA3 marker $[110,111]$. For the flocculent yeast transformation, the lithium acetate method was preferred. In contrast to spheroplast transformation method, which implies cell wall regeneration, the lithium acetate method avoids perturbation of cell walls. In fact, the flocculence ability of yeasts was not affected by the uptake of foreign DNA [111]. It is noteworthy that as the lithium ion inhibits flocculation [33], the cells are dispersed in the uptake DNA phase, and thus present transformation efficiencies similar to nonflocculent cells [111].

Aiming at producing ethanol from lactose-composed raw materials, a flocculent $S$. cerevisiae strain fermenting lactose was constructed [112]. The auxotrophic mutant $\mathrm{A} 3 \mathrm{w}$ was used in a co-transformation procedure using the KR1B-Lac4-1 plasmid [113] together with a linear fragment form YAC4 [112]. The plasmid KR1BLac4-1 harboured the LAC4 gene and LAC12 gene while the linear YAC4 fragment harboured the URA3 gene marker. The recombinant strain was able to grow and fermented the substrate lactose. Even though the recombinant strain was able to flocculate, it presented a different behaviour from the host strain. The flocculation ability from the recombinant strain was more sensitive to environmental conditions than that of the host strain, loosing its ability to flocculate more easily. This observed flocculation instability could be due to the cloning of the lactose permease, a cell membrane protein. Because flocculation is a cell wall phenomenon, 
introduction of a new protein in the cell membrane may interfere with cell-to-cell interaction. Supporting this, the transformation of the same host strain, the mutant A3, with the plasmid pVK1.1 [114] harbouring an extracellular $A$. niger $\beta$-galactosidase, resulted in a recombinant flocculent $S$. cerevisiae strain with the same flocculation ability as the host strain [115]. Nevertheless, the flocculation instability should not be a problem as it can be overcome by a selective bioreactor operation for the flocculent cells [116-118]. The constructed recombinant strain is very attractive for industrial use in cheese whey bio-remediation. As the S. cerevisiae strain is not able to metabolise the sugar lactose, the only carbon source present in cheese whey, there is no need for extra selective pressure: once the recombinant strain looses the plasmid, it will not be able to grow.

Besides ethanol production, flocculent yeast cells can also be used for protein production by secretion. This was demonstrated by constructing two brewer's yeast strains, a flocculent and a non-flocculent, both secreting an Aspergillus niger $\beta$-galactosidase [115]. No significant differences between the $\beta$-galactosidase activity were detected in the supernatants from the non-flocculent and flocculent recombinant brewer's yeast strains. A slight $\beta$-galactosidase accumulation inside the floc was suggested but it seemed that the protein was able to diffuse through the porous floc afterwards [115]. Anyway this can be minimised by using polymeric additives that increase floc porosity $[119,120]$. Protein production using continuous high cell density flocculent systems will be therefore viable and economically attractive, especially when the protein is secreted. In such situation not only the protein separation process is simplified but also an increased overall volumetric productivity can be expected [115].

Other characteristics of industrial importance may be incorporated in flocculent microorganisms. Javadekar et al. [121] introduced the killer character in an industrial flocculent strain of S. cerevisiae (NCIM3528) by protoplast fusion with the $S$. cerevisiae NCIM3578, carrying the killer character.

The development of new flocculent yeast strains is the first step of process optimisation, being the following one the development of the appropriate bioreactor design and operation conditions.

\section{BIOREACTORS FOR YEAST FLOCCULATION}

\section{Bioreactor Design and Operation Conditions}

In continuous fermentation systems, the operation of bioreactors using flocculating organisms implies that the adequate size, shape and density characteristics of the flocs are achieved and maintained, in order to retain biomass inside the bioreactor as much as possible, while keeping the maximum activity. In other words, this means that a balance must be obtained between the capacity of the bioreactor to retain biomass (favoured by an increase in floc size) and the minimisation of the flocs mass transfer limitations (favoured by smaller flocs). This balance depends on the bioreactor hydrodynamic conditions (especially shear stress) and yeast cells flocculation ability and flocs physical properties. Stirred vessels and packed beds are therefore not recommended as flocculation bioreactors (although they may be suitable for other immobilised cell systems which are mechanically more resistant). The use of a fluidised bed for flocculating cultures is not advisable, either, as the density difference between flocs and medium is rather small and fluidisation would be achieved at very low air/liquid flow rates, enhancing the mass transfer limitations already existing. On the contrary, bubble columns and airlift reactors (especially the later) are being extensively used with three-phase systems in processes involving flocculating organisms $[60,118,122-129]$.

The evaluation of the performance of flocculating cultures in airlift reactors depends on the understanding of the interaction between design and operational parameters [130].

As one of the main features of high cell density systems is the high hold-up of the solid phase (that may be as high as $50-60 \%$ of the total bioreactor volume, with the corresponding reduction in liquid phase volume) a significant research effort has been devoted to optimise the design of several parts of three-phase airlift reactors, namely in those aspects related to their use as high cell density systems. As previously stated the use of flocculent microorganisms requires a surplus of attention when designing a reactor in order to keep flocs with the suitable characteristics for the process (shape, density and size, mainly).

\section{Influence of the Solid and Liquid Phases in High Cell Density Bioreactors Hydrodynamics}

In order to increase biomass performance using yeast cell flocs, it is of crucial importance to characterise the properties of the solid phase (particularly solid phase hold-up) and liquid phase [131], and the way they affect the hydrodynamics of flocculation bioreactors. However, no real data are available for flocculation bioreactors and so far, even when systems with similar properties have been used as models, only a few of them deal with solids loads as high as those found in flocculation bioreactors. In fact, solids load may affect gas-liquid mass transfer efficiency [132], gas hold-up $[133,134]$, liquid velocity [135], mixing time [128] and solids hold-up in the different parts of the bioreactor [134], among other parameters.

In flocculation bioreactors, biomass retention is strongly improved when an enlarged top section is used as it permits a better gas disengagement as well as enhanced solids settling [136]. In fact, when a full characterisation of solid phase distribution inside the bioreactor was done, for all tested solids loads and gas flow rates, solids hold-up in the separator has been found to be lower than that in the riser or in the downcomer, thus proving the efficiency of this system in what con- 
cerns solids retention [137].

\section{Mass Transfer in Flocculating Cell Cultures}

Mass transfer limitations in high density flocculating yeast cell cultures are mainly associated with the transport of solutes (being either nutrients or metabolic products) inside the flocs and, although to a smaller extent, to the gas-liquid mass transfer of oxygen from the gas phase to the liquid medium. It is fundamental to quantify these resistances in order to characterise the process and to decide which measures must be taken to minimise their effects in the overall result of the process. Concerning the gas-liquid mass transfer of oxygen, and especially in the case of aerobic fermentations, cell exposure to low or near zero dissolved oxygen concentrations may have a deleterious effect on metabolism, therefore affecting the overall yield of the process. Due to the low solubility of oxygen in fermentation media, there is the need of a continuous $\mathrm{O}_{2}$ supply, either pure or as part of a gaseous mixture (most frequently, air). The design parameters of an airlift as well as the presence of solids may affect gas-liquid oxygen transfer. In the case of the former, the presence of a draught tube and the flow area ratio between riser and downcomer [138] affect significantly the oxygen volumetric mass transfer coefficient $\left(k_{I} a\right)$. The presence of solids usually provokes a decrease of $k_{L} a$, when compared to the value for two-phase operation $[133,139,140]$, and the same happens in the particular case of the solids being yeast cell flocs [129].

Concerning the mass transfer of solutes inside the flocs, diffusion is the most important mechanism and it is generally described using a single parameter, the effective diffusivity $\left(D_{\mathrm{e}}\right)$ which relates the gradient of the characteristic concentration $(c(r, t))$ along the coordinate $r$ at time $t$ to the average diffusive solute flux $\left(J_{\mathrm{D}}\right)$ across the volume of the object in study, which is expressed by Fick's law:

$$
J_{\mathrm{D}}=-D_{\mathrm{e}} \cdot \nabla c(r, t)
$$

Very little work has been done for the characterisation of solutes transport inside flocs [141-143] and the existing data on the diffusivity of glucose and oxygen do not usually refer to the case of cell aggregates (biofilms not included) [144].

The assessment of internal diffusion limitations in yeast flocs was done by Teixeira and Mota [141], using a membrane bioreactor. A diffusion-reaction model was used and the ratio between the specific lactose uptake rates of a flocculating strain (K. marxianus) over a nonflocculating strain (i.e., an effectiveness factor - $\eta$ ) was determined to be 0.50 and its value was related to the importance of mass transfer limitations inside the yeast flocs. The floc porosity was also determined by means of a thermogravimetric balance, obtaining a value of $50.5 \%$. This value increased about $10 \%$ when the flocs were grown in the presence of a polymeric flocculation additive (a cationic resin) causing a corresponding 10\% increase in the value of the effectiveness factor.

This was an example of many of the attempts that have been made in order to reduce diffusional limitations in flocs through the use of polymeric additives $[142,145,146]$. Those additives should enlarge the space between adjacent cells, extending the bridges that link the cells in a floc [119]. In fact, reductions in diffusional limitations have been reported suggesting an increase of the effective diffusion coefficients of the substrates in the floc, whenever some flocculating additives are used. Lima et al. [119] studied the influence of several polymeric additives on specific glucose uptake rate of flocs of $S$. cerevisiae, using the same membrane bioreactor of Teixeira and Mota [141]. An increase of glucose uptake rate by cells in the flocs grown in the presence of additive was always observed when compared to those grown without additive: 19\% for bis [polyoxyethylenebis(amine)] 20,000, more than 50\% for BPA 1,000 and two-fold for Magna Floc LT25. Floc porosity was measured and found to range from $55.7 \%$ (without additive) to $60.5-63.0 \%$ (with additive). The authors proposed a model for the cell arrangement of yeast flocs, characterised by a cubic packing of the cells. This model succeeded in explaining both the increase in the available area for substrate flux inside the floc when a flocculation additive was used, and the consequent increase in the overall reaction rate. Sousa and Teixeira [142] studied the influence of an anionic (Magna Floc LT25) and a cationic polymer (BPA 1,000) on the batch fermentation parameters of the same flocculating $S$. cerevisiae strain. While the cationic polymer showed to have little effect on the kinetic performance of the system, the anionic polymer caused a two-fold decrease of the time needed to obtain total glucose consumption, confirming its positive effect on the reduction of mass transfer limitations inside flocs. Through the calculation of the effectiveness factor $(\eta)$, the same authors [127] estimated the penetration depth of oxygen in the flocs, corresponding to fractions of cells in the floc having oxygen available ranging from $2.4 \%$ to $16.2 \%$. This estimate was made considering that oxygen uptake by yeast follows zero-order kinetics.

The estimation of the penetration depth of the solutes in flocs was also done by using data on substrate diffusion inside flocs and modelling diffusion-reaction phenomena.

The direct measurement of diffusion coefficients in flocs is made difficult by their very fragile nature: in fact, flocs are easily destroyed and this problem becomes more acute with the size increase, namely when dealing with diameters between $2 \mathrm{~mm}$ and $3 \mathrm{~mm}$. Further, floc dimensions and shape are of capital importance to the assessment of $D_{\mathrm{e}}$ [147] and their geometry is seldom a perfectly defined sphere, as it is usually assumed, being flat cylinders and ellipsoids the most common shapes. One of the best procedures to determine their diameter in a non-destructive way is by image analysis. Such a technique applied to yeast flocs has been developed by Vicente et al. [148], where both the floc size distribution of different populations and the 
number of flocs present in the treated samples have been determined fitting a Gauss curve to the experimental data. From there, the values of the average floc size and their respective standard deviation can be calculated.

Libicki et al. [144] calculated the effective diffusivity of nitrous oxide, a non-reactive solute, within cell aggregates of Escherichia coli. Other authors used inactivated cells [143], measuring the oxygen transfer characteristics of aggregates of Solanum aviculare with $3 \mathrm{~mm}$ to $12.5 \mathrm{~mm}$ in diameter. Effective diffusivity of oxygen in deactivated aggregates was found to increase with particle diameter varying between $2 \%$ and $40 \%$ of the molecular diffusivity of oxygen in water at the same temperature. The authors therefore considered that severe oxygen limitations occurred in the aggregate. The same conclusion was drawn by Vicente et al. [149], who studied mass transfer characteristics (effective diffusivity, $D_{e}$, and external mass transfer coefficient, $K_{c}$ ) of glucose and oxygen in flocs $(0.90 \mathrm{~mm}$ to $2.42 \mathrm{~mm}$ in diameter) of $S$. cerevisiae using inactivated cells but a different technique. A modified diffusion cell [150] was used in order to avoid floc destruction. Diffusion coefficients were found to be, for glucose, $17 \%$ of the diffusivity in water and, for oxygen, from $0.2 \%$ to $1 \%$ of the diffusivity in water, which is in agreement with the data from Ananta et al. [143], if the floc size is considered. $K_{c}$ values increased with the agitation rate, as expected, and have values ranging from $7.5 \times 10^{-9} \mathrm{~m} / \mathrm{s}$ to $15 \times 10^{-9} \mathrm{~m} / \mathrm{s}$. These values indicate that both the mass transfer inside and outside the flocs may be a limiting step in this process.

Based on these results, concentration profiles of glucose and oxygen inside aggregates of $S$. cerevisiae were simulated and calculations were made for different possible sizes of the yeast flocs, considering also the presence or the absence of a polymeric additive [151] (Fig. $3(a)$ and (b)).

From Fig. 3 it can be seen that only a small percentage of the cells in the floc metabolise glucose oxidatively, due to severe oxygen limitations. The presence of the polymeric additive, however, increased the ratio of cells operating under respiratory metabolism over those under fermentative metabolism: from $0.4 \%$ to $5.7 \%$, without additive, to $1.2 \%$ to $8.5 \%$, with additive, depending on the bulk glucose concentration.

\section{Operation of Flocculation Bioreactors}

One of the main advantages associated with the operation of yeast flocculation bioreactors is their operational stability and their resistance to contamination by other microorganisms, even those with higher specific growth rates, as it has been clearly demonstrated by Domingues et al. [152]. When operating with a recombinant $S$. cerevisiae strain [112] at a dilution rate of 0.45 $\mathrm{h}^{-1}$, it was possible to significantly reduce an artificially introduced bacterial contamination within $4 \mathrm{~h}$. Operation stability is patent in Fig. 4, where the operation of an external loop airlift with a sedimentation zone (a

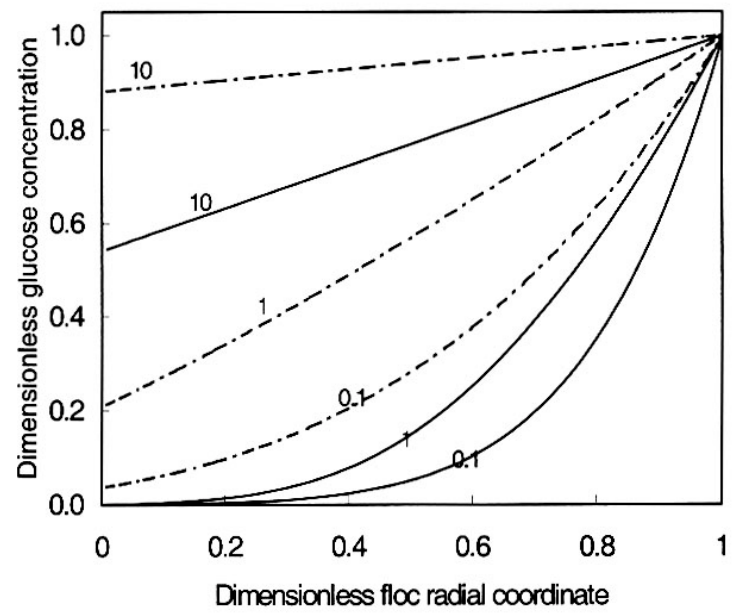

(a)

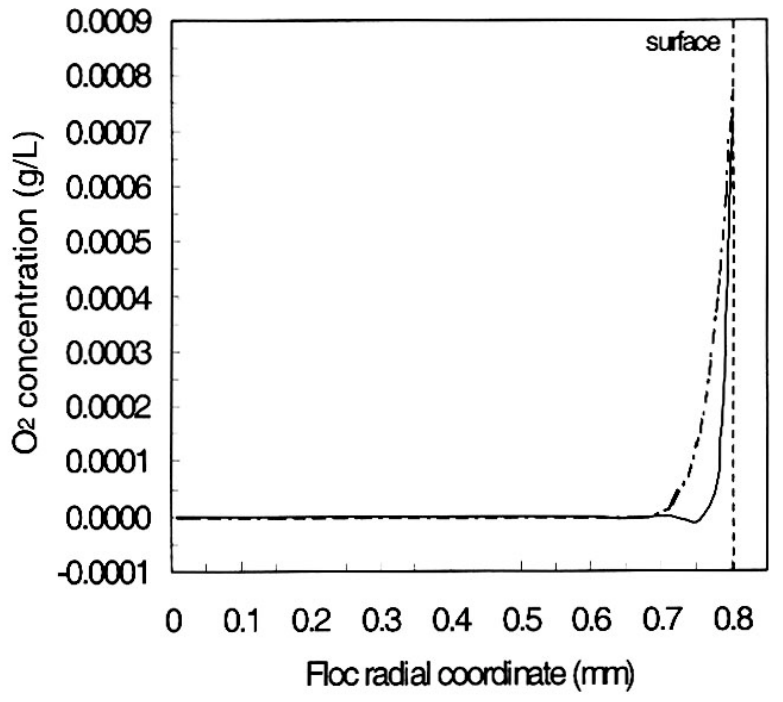

(b)

Fig. 3. Comparison of the concentration profiles for flocs grown with (dot-dashed lines) and without (solid lines) a flocculation additive, with a radius of $0.8 \mathrm{~mm}$ : (a) dimensionless glucose concentration profiles (the parameters near the lines identify the values of the bulk concentration to which each line corresponds), (b) dissolved oxygen concentration profiles.

volume of $1.2 \mathrm{~L}$ and fed at different dilution rates) is shown [153].

This experiment was made with the yeast strain $K$. marxianus ATCC 10002 that, when inoculated in the bioreactor, had no flocculation ability. Being so, during the first 12 days there was no considerable difference between the biomass concentration in the effluent and inside the bioreactor. In the following days, however, flocs became apparent and the biomass concentration started to rise inside the bioreactor, while the effluent biomass concentration was kept near zero. This means that both the hydrodynamic conditions inside the reactor were favourable to the formation of flocs and that there was a selection of the most flocculent individuals 


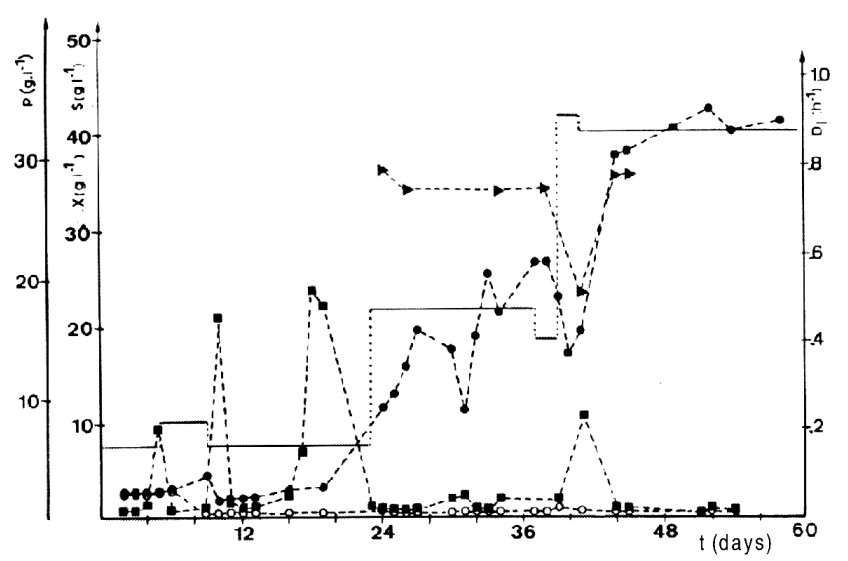

Fig. 4. Flocculation bioreactor response to increasing dilution rate $(D)$ with a feed lactose concentration of $57.2 \mathrm{~g} / \mathrm{L}$; biomass concentration in the bioreactor $(X),(O)$ biomass concentration in the effluent $(X),(\boldsymbol{\square})$ lactose concentration $(S)$, $(\mathbf{A})$ ethanol concentration $(P)$.

in detriment of the non-flocculating ones, due to the sedimentation characteristics of the former. Of particular importance is the fact that it has been possible to keep constant the flocculating characteristics of the strain used during a working period of two years. It is interesting to notice the effects of a sudden increase of the dilution rate (in days 39 to 41), when a peak of lactose concentration together with a drop of both ethanol and biomass concentrations are registered and are essentially due to a washout effect. However, the system reacts and, three days later, a new equilibrium state is reached. Also noteworthy is the biomass concentration in the effluent, which has always very low values throughout the course of the experiment. With this system it has been possible to achieve a practically complete conversion of substrate during an alcoholic fermentation of lactose [117]. A maximum ethanol outlet concentration of $44.8 \mathrm{~g} / \mathrm{L}$ and a maximum ethanol productivity of $24.4 \mathrm{~g} \cdot \mathrm{L}^{-1} \cdot \mathrm{h}^{-1}$ were obtained.

Considering the need to develop new and simpler fermentation systems and the suitability of the airlift bioreactor for cultures using flocculating microorganisms, a $5.4 \mathrm{~L}$ internal loop airlift bioreactor was tested and compared with the previous system [126] using a highly flocculating strain of $S$. cerevisiae growing on glucose. A comparison was made in terms of start-up evolution, overall performance and power costs. The best ethanol productivity was obtained for the concentric tube airlift reactor $\left(12.9 \mathrm{~g} \cdot \mathrm{L}^{-1} \cdot \mathrm{h}^{-1}\right)$, but both systems behaved in a similar way and the productivity values were about seven times higher than those in commercial systems. There was also a clear indication of a higher cell activity in the concentric tube airlift bioreactor when compared to the external loop airlift, thus compensating for the lower cell retention capacity of the former. The power cost analysis revealed differences only at laboratory and pilot scales; at industrial scale, however, the concentric tube airlift is advantageous because no mechanical parts are involved in cell recy- cling. The work proceeded, then, with the concentric tube airlift [127], by studying the evolution of fermentation parameters of the same flocculent strain of $S$. cerevisiae during the start-up of a continuous fermentation. A strong influence of the dilution and aeration rates was found on both biomass and ethanol concentrations and kinetic parameters. The operating parameters, in turn, do not seem to affect glucose consumption rates but affect, instead, the stoichiometry of its conversion to either biomass or ethanol, suggesting a shift in the metabolic mechanisms as biomass builds up. The previously mentioned new flocculent strains were applied in a high cell density concentric tube airlift bioreactor [118]. In continuous operation, an ethanol productivity of $11 \mathrm{~g} \cdot \mathrm{L}^{-1} \cdot \mathrm{h}^{-1}$ was obtained (with a feed lactose concentration of $50 \mathrm{~g} / \mathrm{L}$ and a dilution rate of $0.55 \mathrm{~h}^{-1}$ ), being seven-fold larger than the one in conventional continuous systems. Despite the flocculence instability of the recombinant strain, a high biomass concentration was achieved inside the bioreactor as its design allowed for a selection of the most flocculating cells from a mixed culture, contributing thus with a selective pressure for the maintenance of the flocculating cells inside the bioreactor. The most direct application of this work is the high-productivity fermentation of the lactose present in cheese whey to produce ethanol, not only contributing to the bioremediation of this by-product of the dairy industry produced in large amounts, but also allowing for the production of a useful fuel.

One of the shortcomings of flocculation bioreactors, already mentioned, is the presence of mass transfer limitations inside the flocs. It is possible to calculate a floc critical diameter, defined as the value of diameter at which solid phase diffusion limitations become more important than liquid phase diffusion limitations [147]. A floc diameter greater than its critical value can have consequences such as the presence of useless biomass inside the reactor, undesirable metabolite production by inactive biomass, changes in chemical and biochemical characteristics of medium and microorganisms, suggesting a continuous disintegration of the flocs into a smaller size. In the same line, Webster [154] developed criteria allowing for the assessment of the importance of substrate diffusional limitations within cell flocs, depending on the rate law used to describe substrate consumption. Thus, a reduction in floc size could be expected to bring a reduction in mass transfer limitations, leading to an increase of productivity. Vicente et al. [155] introduced static mixers in the draught tube of the internal loop airlift bioreactor used by Sousa et al. $[126,127]$, achieving an effective reduction of the floc size ( $3 \mathrm{~mm}$ to $1 \mathrm{~mm}$ in diameter). Steady state data at different dilution rates were measured for both systems (the original and the modified bioreactor) and the results were compared in terms of specific consumption/production rates and ethanol productivity. A $40 \%$ increase was obtained in the maximum dilution rate at which a glucose conversion higher than $98 \%$ could be achieved. The respiratory quotient had a constant value (around 23) at all dilution rates, meaning that the meta- 
Table 1. Scientific work using flocculation bioreactors

\begin{tabular}{|c|c|c|c|c|c|c|}
\hline Organism & Reactor type & Volume [L] & Main substrate & Main product & $\begin{array}{l}\text { Productivity } \\
{\left[\mathrm{g} \cdot \mathrm{L}^{-1} \cdot \mathrm{h}^{-1}\right]}\end{array}$ & Ref. \\
\hline S. cerevisiae & bubble column & $1-50$ & wort & beer & - & [157] \\
\hline S. cerevisiae & bubble column & - & molasses & ethanol & $25-30$ & [164] \\
\hline K. marxianus & external loop airlift & 1.2 & lactose & ethanol & 24.4 & [117] \\
\hline S. cerevisiae & external loop airlift & 2 & glucose / sucrose & ethanol & 68 & [165] \\
\hline S. cerevisiae & CSTR & 3 & glucose & ethanol & 5 & [166] \\
\hline S. cerevisiae & series of 2 CSTR & $0.5+1.5$ & molasses & ethanol & 9.3 & [167] \\
\hline S. cerevisiae & internal loop airlift & 5.4 & glucose & ethanol & - & [127] \\
\hline S. cerevisiae & $\begin{array}{l}\text { external }+ \\
\text { internal loop airlift }\end{array}$ & $1.2+5.4$ & glucose & ethanol & 12.9 & [126] \\
\hline S. cerevisiae & fluidised bed & 10 & molasses & ethanol & $15-20$ & [168] \\
\hline S. cerevisiae & external loop airlift & 2 & sucrose & ethanol & - & [169] \\
\hline S. diasctaticus & external loop airlift & 2 & $\begin{array}{l}\text { Jerusalem } \\
\text { artichoke extract }\end{array}$ & $\begin{array}{l}\text { ethanol }+ \\
\text { inulin }\end{array}$ & - & [170] \\
\hline $\begin{array}{l}\text { Z. mobilis + } \\
\text { Saccharomyces sp. }\end{array}$ & agitated conical flasks & 1 & - & ethanol & 1.5 & [171] \\
\hline Rhodiola sachalinensis & internal loop airlift & $10-100$ & - & salidroside & - & [172] \\
\hline S. cerevisiae & internal loop airlift & 6 & green beer & maturated beer & - & [173] \\
\hline $\begin{array}{l}\text { Schizo-saccharomyces } \\
\text { pombe }\end{array}$ & external loop airlift & 1.2 & grape musts & $\begin{array}{l}\text { deacidified } \\
\text { grape musts }\end{array}$ & - & {$[60]$} \\
\hline K. marxianus & internal loop airlift & 1000 & $\begin{array}{l}\text { deproteinised } \\
\text { cheese whey }\end{array}$ & ethanol & - & Unpublished data \\
\hline $\begin{array}{l}\text { Recombinant } \\
\text { S. cerevisiae }\end{array}$ & internal loop airlift & 6 & lactose & ethanol & - & [118] \\
\hline $\begin{array}{l}\text { Recombinant } \\
\text { S. cerevisiae }\end{array}$ & internal loop airlift & 6 & $\begin{array}{l}\text { deproteinised } \\
\text { cheese whey }\end{array}$ & ethanol & - & [174] \\
\hline
\end{tabular}

bolic state of the cells in flocs remained constant, having a strong fermentative metabolism.

The floc size reduction contributed to the higher observed reaction rates, not only by means of an increased dilution rate, but also because of reduced diffusional limitations, leading to a $30 \%$ increase of ethanol productivity when compared with the original system.

\section{Applications of Flocculation Bioreactors}

One of the first commercial applications of the sedimentation characteristics of flocculating microorganisms was made by the brewing industry, back in 1971, in order to facilitate the separation of the yeast cells from beer at the end of the process [156]. Still, it is mostly in the brewing industry that flocculation bioreactors are widely used. However, in this case, flocculation is essentially a separation technique and not a way to immobilise cells in continuous high cell density systems. Despite this, the works with flocculating bioreactors are being performed for some decades, as Smith and Greenshields [157] have successfully grown flocculent strains of brewing yeast in bubble column fermenters. Most brewing companies and brewing research groups have several research works using high cell density bioreactors, mostly with airlift configuration, in order to investigate their potential use in continuous beer fermentation, with the advantages pointed out throughout the preceding text [158-163]. Neverthe- less, none of these works actually deals with flocculating cultures, though some mention them as a possible alternative to the existing processes, in particular for beer maturation [158].

In Table 1, a summary of works with flocculation bioreactors is presented, proving an emerging interest for this type of systems. As can be seen, the majority of the work presented deals with flocculating microorganisms for continuous ethanol production, which is not surprising since, for the moment, continuous high cell density systems are adequate for high volume low added value products. Recently, protein secretion by flocculating yeast cells has been reported as another possible application for high cell density bioreactors [115].

As also indicated, most of the studies on flocculation bioreactors have been done in bench-scale apparatuses due to costs and complexity involved in larger scale research. Being so, further information on hydrodynamics and mass transfer needed for reactor scale-up is still missing and it is not surprising that, so far, industry still hesitates to select a flocculation-based process for commercial purpose, in spite of the operational advantages of these systems.

\section{CONCLUSION}

Known for several years, yeast flocculation is a phenomenon that has not yet been fully clarified. To date, 
three mechanisms have been invoked to explain the yeast flocculation: the colloidal theory, the $\mathrm{Ca}^{2+}$ bridge theory and the lectin-model theory. The lectin-model theory is the widely accepted model but, as suggested by Speers et al. [63], it may happen that more than one of these models is operative, as experimental data accumulate indicating that different mechanisms for flocculation exist in different yeast strains and environmental conditions.

At industrial scale, only beer producers have taken advantage of yeast flocculation ability by using this property to clarify the fermented must. This is a rather limited application of flocculating yeast cells as, at laboratory and pilot plant scale, the advantages of continuous bioreactors for the production of ethanol (a primary metabolite) have been clearly demonstrated. More recently, the advantages of these bioreactors for the production of an enzyme have also been demonstrated, indicating the potential use of flocculent yeast cells in the emerging proteins, vitamins and co-factors production through recombinant DNA technology. Flocculating properties of yeast cells can be used either to increase overall productivity in continuous bioreactors by allowing for high biomass retention or to facilitate downstream processing in continuous, fed-batch or batch reactors.

In conclusion, it may be said that there is the need for more research on flocculent yeast strains and high cell density systems, in general, and on flocculation bioreactors, in particular, in order to gather the necessary information to make them an interesting alternative to the processes used nowadays, which are in most cases very well established and studied. The potential surely exists in this new technology, but it has to be demonstrated before the industry risks investing largely in it.

Acknowledgments Author L. Domingues gratefully acknowledges the financial support from Fundação para a Ciência e a Tecnologia, through the grant Praxis XXI/ BD11306/97.

\section{REFERENCES}

[1] Eddy, A. A. and M. A. D. Phil (1958) Composite nature of the flocculation process of top and bottom strains of Saccharomyces. J. Inst. Brew. 64: 143-151.

[2] Mill, P. J. (1964) The nature of the interaction between flocculent cells in the flocculation of Saccharomyces cerevisiae. J. Gen. Microbiol. 35: 61-68.

[3] Speers, R. A., M. A. Tung, T. D. Durance, and G. G. Stewart (1992) Colloidal aspects of yeast flocculation: a review. J. Inst. Brew. 98: 525-531.

[4] Calleja, G. B. (1973) Role of mitochondria in the sexdirected flocculation of a fission yeast. Arch. Biochem. Biophysics 154: 382-386.

[5] Stewart, G. G., I. Russell, and I. F. Garrison (1973). Further studies on flocculation and co-flocculation in brewer's yeast strains. Amer. Soc. Brew. Chem. Proc: 100106.

[6] Nishihara, H., T. Toraya, and S. Fukui (1976). Induction of floc-forming ability in brewer's yeast. J. Ferment. Technol. 54: 356-360.

[7] Nishihara, H., T. Toraya, and S. Fukui (1977). Effect of chemical modification of cell surface components of a brewer's yeast on the floc-forming ability. Arch. Microbiol. 115: 19-23.

[8] Nishihara, H. (1979) Effect of physical, chemical and enzymatic treatments on the floc-forming ability of intact cells and/or cell walls of a brewer's yeast. Mem. Fac. Educ. Kagawa Univ. II 20: 69-74.

[9] Nishihara, H. and M. Ueda (1979) Effect of chemical modification of proteins on the cell walls of a brewer's yeast on the floc-forming ability. Mem. Fac. Educ. Kagawa Univ. II 29: 61-68.

[10] Nishihara, H., T. Toraya, and S. Fukui (1982) Flocculation of cell walls of brewer's yeast and effects of metal ions, protein-denaturants and enzyme treatments. Arch. Microbiol. 131: 112-115.

[11] Teixeira, J., M. H. Gonçalves, F. M. Gama, P. MoradasFerreira, and M. Mota (1989) Partial characterization of cell wall from a flocculent strain of Kluyveromyces marxianus. Biotechnol. Lett. 11: 579-582.

[12] Amri, M. A., R. Bonaly, B. Duteurtre, and M. Moll (1981) Caractérisation des constituants pariétaux impliqués dans la flocculation de levures Saccharomyces uvarum. Biochimie 63: 575-585.

[13] Miki, B. L. A., N. H. Poon, A. P. James, and V. L. Seligy (1982) Possible mechanism for flocculation interactions governed by gene FLO1 in Saccharomyces cerevisiae. J. Bacteriol. 150: 878-889.

[14] Taylor, N. W. and W. L. Orton (1978) Aromatic compounds and sugars in [56] flocculation of Saccharomyces cerevisiae. J. Inst. Brew. 84: 113-114.

[15] Nishihara, H. and T. Toraya (1987) Essential role of cell surface protein and carbohydrate components in flocculation of a brewer's yeast. Agric. Biol. Chem. 51: 27212726.

[16] Stratford, M. (1992) Yeast flocculation: receptor definition by mnn mutants and Concanavalin A. Yeast 8: 635 645.

[17] Bilang, M., F. Attioui, V. Loppinet, J.-C. Michalski, and R. Bonaly (1996) Structure of the phosphopeptidomannans from flocculent and non-flocculent yeast Kluyveromyces lactis. Carbohydrate Res. 280: 303-313.

[18] Moradas-Ferreira, P., P. A. Fernandes, and M. J. Costa (1994) Yeast flocculation-the role of cell wall proteins. Colloid Surf. B: Biointerf. 2: 159-164.

[19] Nagarajan, L. and S. Umesh-Kumar (1990) Antigenic studies on flocculating brewer's yeast, Saccharomyces cerevisiae NCYC 227. J. Gen. Microbiol. 136: 1747-1751.

[20] Stewart, G. G., I. F. Garrison, T. E. Goring, M. Meleg, P. Pipasts, and I. Russell (1976) Biochemical and genetic studies on yeast flocculation. Kemia-Kemi 10: 465-479.

[21] Fernandes, P. A., J. N. Keen, J. B. C. Findlay, and P. Moradas-Ferreira (1992) A protein homologous to glyceraldehyde-3-phosphate dehydrogenase is induced in the 
cell wall of a flocculent Kluyveromyces marxianus. Biochim. Biophys. Acta 1159: 67-73.

[22] Fernandes, P. A., M. Sousa, and P. Moradas-Ferreira (1993) Flocculation of Kluyveromyces marxianus is induced by a temperature upshift. Yeast 9: 859-866.

[23] Saito, K., S. Sato, H. Shimoi, H. Iefuji, and M. Tadenuma (1990) Flocculation mechanism of Hansenula anomala J224. Agric. Biol. Chem. 54: 1425-1432.

[24] Holmberg, S. (1978) Isolation and characterization of a polypeptide absent from non-flocculent mutants of Saccharomyces cerevisiae. Carlsberg Res. Commun. 43: 401-413.

[25] Watari, J., Y. Takata, N. Nishikawa, and K. Kamuda (1987) Cloning of a gene controlling yeast flocculence. Proc. Eur. Brew. Conv. Congr: 537-544, Madrid.

[26] Robertson (1980) Can. J. Biochem. 58: 565-572.

[27] Moreira, R. F., P. A. Fernandes, and P. Moradas-Ferreira (1998) Kluyveromyces marxianus flocculence and growth at high temperature is dependent on the presence of the protein p37. Microbiol. 144: 681-688.

[28] Al-Mahmood, S., P. Giummelly, R. Bonaly, F. Delmotte, and M. Monsigny (1988) Kluyveromyces bulgaricus yeast lectins. Isolation of $\mathrm{N}$-acetylglucosamine and galactosespecific lectins: their relation with flocculation. J. Biol. Chem. 263: 3930-3934.

[29] Al-Mahmood, S., S. Colin, and R. Bonaly (1991) Kluyveromyces bulgaricus yeast lectins. Isolation of two galactose-specific lectin forms from the yeast cell wall. $J$. Biol. Chem. 266: 20882-20887.

[30] Straver, M. H., V. M. Traas, G. Smit, and J. W. Kijne (1994) Isolation and partial purification of mannose-specific agglutinin from brewer's yeast involved in flocculation. Yeast 10: 1183-1193.

[31] Shankar, C. S. and S. Umesh-Kumar (1994) A surface lectin associated with flocculation in brewing strains of Saccharomyces cerevisiae. Microbiol. 140: 1097-1101.

[32] Javadekar, V. S., H. Sivaraman, S. R. Sainkar, and M. I. Khan (2000) A mannose-binding protein from the cell surface of flocculent Saccharomyces cerevisiae (NCIM 3528): its role in flocculation. Yeast 16: 99-110.

[33] Stratford, M. (1989) Yeast flocculation: calcium specificity. Yeast 5: 487-496.

[34] Stratford, M. and S. Assinder (1991) Yeast flocculation: Flo1 and New Flo phenotypes and receptor structure. Yeast 7: 559-574.

[35] Hussain, T., O. Salhi, J. Lematre, C. Charpentier, and R. Bonaly (1986) Comparative studies of flocculation and deflocculation of Saccharomyces uvarum and Kluyveromyces bulgaricus. Appl. Microbiol. Biotechnol. 25: 232-237.

[36] El-Behari, M., J.N. Ekomé, J. Coulon, B. Pucci, and R. Bonaly (1998) Comparative extraction procedures for a galactose-specific lectin involved in flocculation of Kluyveromyces lactis strains. Appl. Microbiol. Biotechnol. 49: 16-23.

[37] Sousa, M. J., J. A. Teixeira, and M. Mota (1992) Differences in the flocculation mechanism of Kluyveromyces marxianus and Saccharomyces cerevisiae. Biotechnol. Lett. 14: 213-218.

[38] Zarattini, R. A., J. W. Williams, J. R. Ernandes, and G. G. Stewart (1993) Bacterial-induced flocculation in selected brewing strains of Saccharomyces. Cerevisiae 4: 65-70.

[39] Stratford, M. (1992) Yeast flocculation: a new perspective. Adv. Microb. Physiol. 33: 1-71.

[40] Stewart, G. G., I. Russell, and I. F. Garrison (1975) Some considerations of the flocculation characteristics of ale and lager yeast strains. J. Inst. Brew. 81: 248-257.

[41] Speers, R. A., T. D. Durance, P. Odense, S. Owen, and M. A. Tung (1993) Physical properties of commercial brewing yeast suspensions. J. Inst. Brew. 99: 159-164.

[42] Teunissen, A. W. R. H., and H. Y. Steensma (1995) Review: The dominant flocculation genes of Saccharomyces cerevisiae constitute a new subtelomeric gene family. Yeast 11: 1001-1013.

[43] Masy, C. L., A. Henquinet, and M. M. Mestdagh (1992) Flocculation of Saccharomyces: inhibition by sugars. Can.J. Microbiol. 38: 1298-1306.

[44] Watari, J., T. Yoshihiro, M. Ogawa, H. Sahara, S. Koshino, M.-L. Onnela, U. Airaksinen, R. Jaatinen, M. Penttilä, and S. Keränen (1994) Molecular cloning and analysis of the yeast flocculation gene FLO1. Yeast 10: 211-225.

[45] Bony, M., D. Thines-Sempoux, P. Barre, and B. Blondin (1997) Localization and cell surface anchoring of the Saccharomyces cerevisiae flocculation protein Flo1p. J. Bacteriol. 179: 4929-2936.

[46] Kobayashi, O., N. Hayashi, R. Kuroki, and H. Sone (1998) Region of Flo1 proteins responsible for sugar recognition. J. Bacteriol. 180: 6503-6510.

[47] Bony, M., P. Barre, and B. Blondin (1998) Distribution of the flocculation protein, Flop, at the cell surface during yeast growth: the availability of Flop determines the flocculation level. Yeast 14: 25-35.

[48] Teixeira, J. and M. Mota (1987) Isolation of a flocculating strain of $K$. marxianus by a continuous method. Abstracts of the $4^{\text {th }}$ Eur. Conf. Biomass for Energy and Ind: 273-274.

[49] Smit, G., M. H. Straver, B. J. J. Lugtenberg, and J. W. Kijne (1992) Flocculence of Saccharomyces cerevisiae cells is induced by nutrient limitation, with cell surface hydrophobicity as a major determinant. Appl. Environ. Microbiol. 58: 3709-3714.

[50] Lambrechts, M. G., F. F. Bauer, J. Marmur, and I. S. Pretorius (1996) MucI, a mucin-like protein that is regulated by Mss10, is critical for pseudohyphal differentiation in yeast. Proc. Natl. Acad. Sci. USA 93: 8419-8424.

[51] Liu, H., C. A. Styles, and G. R. Fink (1996) Saccharomyces cerevisiae $\mathrm{S} 288 \mathrm{C}$ has a mutation in FLO8, a gene required for filamentous growth. Genetics 144: 867-978.

[52] Lo, W.-S. and A. M. Dranginis (1998) The cell surface flocculin Flo11 is required for pseudohyphae formation and invasion by Saccharomyces cerevisiae. Mol. Biol. Cell 9: 161-171.

[53] Rose, A. H. (1984) Physiology of cell aggregation. Flocculation by Saccharomyces cerevisiae as a model system. pp. 323-335. In: K. C. Marshall (ed.) Microbial Adhesion and Aggregation.

[54] Taylor, N. W. and W. L. Orton (1973) Effect of alkalineearth metal salts on flocculence in Saccharomyces cerevisiae. J. Inst. Brew. 79: 294-297.

[55] Kuriyama, H., I. Umeda, and H. Kobayashi (1991) Role of cations in the flocculation of Saccharomyces cerevisiae and 
discrimination of the corresponding proteins. Can. J. Microbiol. 37: 397-403.

[56] Stewart, G. G. and T. E. Goring (1976) Effect of some monovalent and divalent metal ions on the flocculation of brewer's yeast strains. J. Inst. Brew. 82: 341-342.

[57] Amry, M. A., R. Bonaly, B. Duteurtre, and M. Moll (1979) Interrelation between $\mathrm{Ca}^{2+}$ and $\mathrm{K}^{+}$ions in the flocculation of two brewer yeast strains. Eur. J. Appl. Microbiol. Biotechnol. 7: 235-240.

[58] Stratford, M. and H. M. Brundish (1990) Yeast flocculation: cationic inhibition. Yeast 6: 77-86.

[59] Kihn, J. C., C. L. Masy, and M. M. Mestdagh (1988) Yeast flocculation: competition between non-specific repulsion and specific bonding in cell adhesion. Can. J. Microbiol. 34: 773-778.

[60] Sousa, M. J., J. A. Teixeira, and M. Mota (1993) Must deacidification with an induced flocculant yeast strain of Schizosaccharomyces pombe. Appl. Microbiol. Biotechnol. 39: 189-193.

[61] Stratford, M. (1996) Induction of flocculation in brewing yeasts by change in $\mathrm{pH}$ value. FEMS Microbiol. Lett. 136: 13-18.

[62] Yang, Y. L. and C. Y. Choi (1998) Induction of flocculation of Saccharomyces cerevisiae by a $\mathrm{pH}$-upshift. Biotechnol. Tech. 12: 591-593.

[63] Speers, R. A., M. A. Tung, T. D. Durances, and G. G. Stewart (1992) Biochemical aspects of yeast flocculation and its measurement: A review. J. Inst. Brew. 98: 293-300.

[64] Straver, M. H., P. C. van der Aar, G. Smit, and J.W. Kijne (1993) Determinants of flocculence of brewer's yeast during fermentation in wort. Yeast 9: 527-532.

[65] Amory, D. E., P. G. Rouxhet, and J. P. Dufour (1988) Flocculence of brewery yeasts and their surface properties: chemical composition, electrostatic charge and hydrophobicity. J. Inst. Brew. 94: 79-84.

[66] Straver, M. H., J. W. Kijne, and G. Smit (1993) Cause and control of flocculation in yeast. Trends Biotechnol. 11: 228232.

[67] Wilcocks, K. L. and K. A. Smart (1995) The importance of surface charge and hydrophobicity for the flocculation of chain-formation brewing yeast strains and resistance of these parameters to acid washing. FEMS Microbiol. Lett. 134: 293-297.

[68] Teixeira, J. A., R. Oliveira, J. Azeredo, M. Sousa, and C. Sil (1995) Cell wall surface properties and flocculence of a Kluyveromyces marxianus strain. Colloid Surf. B: Biointerf. 5: 197-203.

[69] Straver, M. H. and J. W. Kijne (1996) A rapid and selective assay for measuring cell surfaces hydrophobicity of brewer's yeast cells. Yeast 12: 207-213.

[70] Miki, B. L. A., N. H. Poon, and V. L. Seligy (1982) Repression and induction of flocculation interactions in Saccharomyces cerevisiae. J. Bacteriol. 150: 890-899.

[71] Soares, E. V., J. A. Teixeira, and M. Mota (1991) Influence of aeration and glucose concentration in the flocculation of Saccharomyces cerevisiae. Biotechnol. Lett. 13: 207-212.

[72] Stratford, M. and M. H. J. Keenan (1988) Yeast flocculation: quantification. Yeast 4: 107-115.
[73] Mozes, N., L. L. Schinckus, C. Ghommidh, J.-M. Navarro, and P. G. Rouxhet (1994) Influence of medium composition on surface properties and aggregation of a Saccharomyces cerevisiae strain. Colloids Surf. B: Biointerf. 3: 63-74.

[74] Burrel, K. (1996) Flocculation, fluid dynamics and fining. The Brewer Feb: 59-60, 62.

[75] Brohan, B. and A. J. McLoughlin (1984) Characterization of the physical properties of yeast flocs. Appl. Microbiol. Biotechnol. 20: 16-22.

[76] Straford, M., H. P. Coleman, and M. H. J. Keenan (1988) Yeast flocculation: a dynamic equilibrium. Yeast 4: 199208.

[77] Gilliland, R. B. (1951) The flocculation characteristics of brewing yeasts during fermentation. Proc. Eur. Brew. Conv. Congr: $35-58$, Brighton.

[78] Thorne, R. S. W. (1951) Some aspects of yeast flocculence. Proc. Eur. Brew. Congr. Brighton: 21-34.

[79] Windish, S. (1968) Flocculation of brewer's yeasts. The Brewer's Digest Nov: 62-66.

[80] Lewis, C. W. and J. R. Johnston (1974) Genes controlling flocculation in yeast. Proc. Soc. Gen. Microbiol. 1: 73-78.

[81] Johnston, J. R. and C. W. Lewis (1974) Genetic analysis of flocculation in Saccharomyces cerevisiae and tetrad analysis of commercial brewing and baking strains. pp. 339-355. In: K. D. MacDonald (ed.) Second International Symposium on the Genetics of Industrial Microorganisms. Academic Press, London.

[82] Lewis, C. W., J. R. Johnston, and P. A. Martin (1976) The genetics of yeast flocculation. J. Inst. Brew. 82: 158-160.

[83] Stewart, G. G. and I. Russell (1977) The identification, characterization, and mapping of a gene for flocculation in Saccharomyces sp. Can. J. Microbiol. 23: 441-447.

[84] Russell, I., G. G. Stewart, H. P. Reader, J. R. Johnston, and P. A. Martin (1980) Revised nomenclature of genes that control yeast flocculation. J. Inst. Brew. 86: 120-121.

[85] Lo, W.-S. and A. M. Dranginis (1996) FLO11, a yeast gene related to the STA genes, encodes a novel cell surface flocculin. J. Bacteriol. 178: 7144-7151.

[86] Sieiro, C., N. M. Reboredo, P. Blanco, and T. G. Villa (1997) Cloning of a new FLO gene from the flocculating Saccharomyces cerevisiae IM1-8b strain. FEMS Microbiol. Lett. 146: 109-115.

[87] Yamashita, I. and S. Fukui (1983) Mating signals control expression of both starch fermentation genes and a novel flocculation gene FLO8 in the yeast Saccharomyces cerevisiae. Agric. Biol. Chem. 47: 2889-2896.

[88] Yamashita, I. and S. Fukui (1984) Genetic background of glucoamylase production in the yeast Saccharomyces. Agric. Biol. Chem. 48: 137-141.

[89] Sieiro, C., E. Longo, J. Cansado, J. B. Velasquez, P. Calo, P. Blanco, and T. G. Villa (1993) Genetic evidence for a new flocculation suppressor gene in Saccharomyces cerevisiae. FEMS Microbiol. Lett. 112: 25-30.

[90] Teunissen, A. W. R. H., E. Holub, J. van dern Hucht, J. A. van der Berg, and H. Y. Steensma (1993) Sequence of the open reading frame of the FLO1 gene from Saccharomyces cerevisiae. Yeast 9: 423-427.

[91] Watari, J., Y. Takata, M. Ograwa, N. Nishikawa, and K. 
Minoru (1989) Molecular cloning of a flocculation gene in Saccharomyces cerevisiae. Agric. Biol. Chem. 53: 901-903.

[92] Stratford, M. (1992) Yeast flocculation: Reconciliation of physiological and genetic viewpoints. Yeast 8: 25-38.

[93] Teunissen, A. W. R. H., J. A. van der Berg, and H. Y. Steensma (1995) Localization of the dominant flocculation genes FLO5 and FLO8 of Saccharomyces cerevisiae. Yeast 11: 735-745.

[94] Kobayashi, O., H. Suda, T. Ohtani, and H. Sone (1996) Molecular cloning and analysis of the dominant flocculation gene FLO8 from Saccharomyces cerevisiae. Mol. Gen. Genet. 251: 707-715.

[95] Vezinhet, F., B. Blondin, and P. Barre (1991) Mapping of the FLO5 gene of Saccharomyces cerevisiae by transfer of a chromosome during cytoduction. Biotechnol. Lett. 13: 4752 .

[96] Bidard, F., B. Blondin, S. Dequin, F. Vezinhet, and P. Barre (1994) Cloning and analysis of a FLO5 floccula-tion gene from S. cerevisiae. Curr. Genet. 25: 196-201.

[97] Hinrichs, J., U. Stahl, and K. Esser (1988) Flocculation in Saccharomyces cerevisiae and mitochondrial DNA structure. Appl. Microbiol. Biotechnol. 29: 48-54.

[98] Bossier, P., P. Goethals, and C. Rodrigues-Pousada (1997) Constitutive flocculation in Saccharomyces cerevisiae through overexpression of the GTS1 gene, coding for a "Glo"-type Zn-finger-containing protein. Yeast 13: 717725.

[99] Moreira, R. F, F. Ferreira-da-Silva, P. A. Fernandes, and P. Moradas-Ferreira (2000) Flocculation of Saccharomyces cerevisiae is induced by transformation with the GAP1 gene from Kluyveromyces marxianus. Yeast 16: 231-240.

[100] Smart, K. A. (1995) The importance of the cell brewing yeast cell wall. Brewer's Guardian April: 43-50.

[101] Barney, M. C., G. P. Jansen, and J. R. Helbert (1980) Use of genetic transformation for the introduction of flocculence into yeast. Amer. Soc. Brew. Chem. J. 38: 71-74.

[102] Figueroa, L. I., M. F. Richard, and M. R. van Broock (1984) Transfer of the flocculation property to the baker's yeast Saccharomyces cerevisiae by conventional genetic manipulation. Biotechnol. Lett. 6: 171-176.

[103] Lima, N., C. Moreira, J. A. Teixeira, and M. Mota (1995) Introduction of flocculation into industrial yeast, Saccharomyces cerevisiae saké, by protoplast fusion. Microbios 81: 187-197.

[104] Watari, J., M. Kudo, N. Nishikawa, and M. Kamimura (1990) Construction of a flocculent yeast cells (Saccharomyces cerevisiae) by mating or protoplast fusion a yeast cell containing the flocculation gene FLO5. Agric. Biol. Chem. 54: 1677-1681.

[105] Watari, J., Y. Takata, M. Ogawa, J. Murakami, and S. Koshino (1991) Breeding of flocculent industrial Saccharomyces cerevisiae strains by introducing the flocculation gene FLO1. Agric. Biol. Chem. 55: 1547-1552.

[106] Watari, J., M. Nomura, H. Sahara, and S. Koshino (1994) Construction of flocculent brewer's yeast by chromosomal integration of the yeast flocculation gene FLO1. J. Inst. Brew. 100: 73-77.

[107] Shinohara, T., Mamiya, S., and Yanagida, F. (1997) Intro- duction of flocculation property into wine yeasts (Saccharomyces cerevisiae) by hybridization. J. Ferment. Bioeng. 83: 96-101.

[108] Hodgson, J. A., D. R. Berry, and J. R. Johnston (1985) Discrimination by heat and proteinase treatments between flocculent phenotypes conferred on Saccharomyces cerevisiae by the genes FLO1 and FLO5. J. Gen. Microbiol. 131: 3219-3227.

[109] Hammond, J. R. M. (1995) Genetically-modified brewing yeasts for the $21^{\text {st }}$ century. Progress to date. Yeast 11: 1613-1627.

[110] Venâncio, A., N. Lima, and M. Mota (1995) Genetic transformation of intact industrial flocculating yeast cells (Saccharomyces cerevisiae) by using lithium acetate and YAC4 plasmid. Yeast 11: 607.

[111] Venâncio, A., L. Domingues, and N. Lima (1999) Transformation of a flocculating Saccharomyces cerevisiae using lithium acetate and pYAC4. J. Basic Microbiol. 1: 37-41.

[112] Domingues, L., J. A. Teixeira, and N. Lima (1999) Construction of a flocculent Saccharomyces cerevisiae fermenting lactose. Appl. Microbiol. Biotechnol. 51: 621-626.

[113] Sreekrishna, K. and R. C. Dickson (1985) Construction of strains of Saccharomyces cerevisiae that grow on lactose. Proc. Natl. Acad. Sci. USA 82: 7909-7913.

[114] Kumar, V., S. Ramakrishna, T. T. Teeri, J. K. C. Knowles, and B. S. Hartley (1992) Saccharomyces cerevisiae cells secreting an Aspergillus niger $\beta$-galactosidase grown on whey permeate. Biotechnology 10: 82-85.

[115] Domingues, L., M.-L. Onnela, J. A. Teixeira, N. Lima, and M. Penttilä (2000) Construction of a flocculent brewer's yeast strain secreting Aspergillus niger $\beta$ galactosidase. Appl. Microbiol. Biotechnol. 54: 97-103.

[116] Mota, M. and J. A. Teixeira (1990) Utilization of an external loop bioreactor for the isolation of a flocculating strain of Kluyveromyces marxianus. Curr. Microbiol. 20: 209-214.

[117] Teixeira, J. A., M. Mota, and G. Goma (1990) Continuous ethanol production of a flocculating strain of Kluyveromyces marxianus: bioreactor performance. Bioprocess Eng. 5: 123-127.

[118] Domingues, L., M. M. Dantas, N. Lima, and J. A. Teixeira (1999) Continuous ethanol fermentation of lactose by a recombinant flocculating Saccharomyces cerevisiae strain. Biotechnol. Bioeng. 64: 692-697.

[119] Lima, N., J. A. Teixeira, and M. Mota (1992) Enhancement of metabolic rates of yeast flocculent cells through the use of polymeric additives. Bioprocess Eng. 7: 343-348.

[120] Sousa, M. L. and J. A. Teixeira (1994) An explanation for the interaction mechanism of an anionic polymeric additive on yeast flocculent cells. Biotechnol. Lett. 16: 751754.

[121] Javadekar, V. S., H. SivaRaman, and D. V. Gokhale (1995) Industrial yeast strain improvement: construction of a highly flocculent yeast with a killer character by protoplast fusion. J. Ind. Microbiol. 15:94-102.

[122] Onken, U. and P. Weiland (1983) Airlift fermenters: construction, behavior, and uses. pp. 67-95. In: Advances in Biotechnological Processes 1. Alan R. Liss, Inc., New York, 
USA.

[123] Kennard, M. and M. Janekeh (1991) Two- and threephase mixing in a concentric tube gas-lift fermentor. Biotechnol. Bioeng. 38: 1261-1270.

[124] Siegel, M. H. and C. W. Robinson (1992) Applications of airlift gas-liquid-solids reactors in biotechnology. Chem. Eng. Sci. 47: 3215-3229.

[125] Merchuk, J. C., N. Ladwa, A. Cameron, M. Bulmer, and A. Pickett (1994) Concentric-tube airlift reactors: effects of geometrical design on performance. AIChE J. 40: 1105-1117.

[126] Sousa, M. L., J. A. Teixeira, and M. Mota (1994) Comparative analysis of ethanolic fermentation in two continuous flocculation bioreactors and effect of flocculation additive. Bioprocess Eng. 11: 83-90.

[127] Sousa, M. L., M. Mota, and J. A. Teixeira (1994) Influence of operational parameters on the start-up of a flocculation airlift bioreactor. Col. Surf. B: Biointerfaces 2: 181-188.

[128] Ganzeveld, K. J., Y. Chisty, and M. Moo-Young (1995) Hydrodynamic behaviour of animal cell microcarrier suspensions in split-cylinder airlift bioreactors. Bioprocess Eng. 12: 239-247.

[129] Sousa, M. L. and J. A. Teixeira (1996) Characterization of oxygen uptake and mass transfer in flocculent yeast cell cultures with or without a flocculation additive. Biotechnol. Lett. 18: 229-234.

[130] Michalski, H. J. (1992) Air-lift bioreactors. In: M. Berovic and T. Koloini, (eds.) Bioreactor Engineering Course Workshop Notes. Italy.

[131] Freitas, C. and J. A. Teixeira (1998) Effect of liquid-phase surface tension on hydrodynamics of a three-phase airlift bioreactor with an enlarged degassing zone. Bioprocess Eng. 19: 451-457.

[132] Smith, B. C. and D. R. Skidmore (1990) Mass transfer phenomena in an airlift reactor: effects of solids loading and temperature. Biotechnol. Bioeng. 35: 483-491.

[133] Siegel, M. H., M. Hallaile, M. Herskowitz, and J. C. Merchuk (1988) Hydrodynamics and mass transfer in a three-phase airlift reactor. Proceedings of the $2^{\text {nd }}$ International Conference on Bioreactor Fluid Dynamics, September 21-23.

[134] Freitas, C. and J. A. Teixeira (1997) Hydrodynamic studies in an airlift reactor with and enlarged degassing zone. Bioprocess Eng. 18: 267-279.

[135] Lu, W.-J., S.-J. Hwang, and C.-M. Chang (1995) Liquid velocity and gas holdup in three-phase internal loop airlift reactors with low density particles. Chem. Eng. Sci. 50: 1301-1310.

[136] Vicente, A. A. and J. A. Teixeira (1995) Hydrodynamic performance of a three-phase airlift bioreactor with an enlarged degassing zone. Bioprocess Eng. 14: 17-22.

[137] Freitas, C. and J. A. Teixeira (1998) Solid-phase distribution in an airlift reactor with an enlarged degassing zone. Biotechnol. Tech. 12: 219-224.

[138] Karamanev, D. G., T. Nagamune, and I. Endo (1992) Hydrodynamic and mass transfer study of a gas-liquidsolid draft tube spouted bed bioreactor. Chem. Eng. Sci.
47: 3581-3588.

[139] Verlaan, P. and J. Tramper (1987) Hydrodynamics, axial dispersion and gas-liquid oxigen transfer in an airlift loop bioreactor with three-phase flow. Proceedings of the International Conference on Bioreactors and Biotransformations. November 9-12. Gleneagles, Scotland.

[140] Komáromy, P. and C. Sisak (1994) Investigation of gasliquid oxygen transport in three-phase bioreactor. Hungarian J. Ind. Chemstry 22: 147-151.

[141] Teixeira, J. A. and M. Mota (1990) Experimental assessment of internal diffusion limitations in yeast flocs. Chem. Eng. J. 43: B13-B17.

[142] Sousa, M. L. and J. A. Teixeira (1991) Reduction of diffusional limitations in yeast flocs. Biotechnol. Lett. 13: 883888.

[143] Ananta, I., M. A. Subroto, and P. M. Doran (1995) Oxygen transfer and culture characteristics of selfimmobilized Solanum aviculare aggregates. Biotechnol. Bioeng. 47: 541-549.

[144] Libicki, S. B., P. M. Salmon, and C. R. Robertson (1988) The effective diffusive permeability of a nonreacting solute in microbial cell aggregates. Biotechnol. Bioeng. 32: 68-85.

[145] Weir, S., D. K. Ramsden, J. Hughes, and F. Le-Thomas (1994) The strength of yeast flocs produced by the cationic flocculant chitosan: Effect of suspension medium and of pretreatment with anionic polyelectrolytes. Biotechnol. Tech. 8: 129-132.

[146] Salt, D. E., A. C. Bentham, S. Hay, A. Idris, J. Gregory, M. Hoare, and P. Dunnill (1996) The mechanism of flocculation of a Saccharomyces cerevisiae cell homogenate using polyethyleneimine. Bioprocess Eng. 15: 71-76.

[147] Hamdi, M. (1995) Biofilm thickness effect on the diffusion limitation in the bioprocess reaction: Biofloc critical diameter significance. Bioprocess Eng. 12: 193-197.

[148] Vicente, A., J. M. Meinders, and J. A. Teixeira (1996) Sizing and counting of Saccharomyces cerevisiae floc populations by image analysis, using an automatically calculated threshold. Biotechnol. Bioeng. 51: 673-678.

[149] Vicente, A. A., M. Dluhý, E. C. Ferreira, M. Mota, and J. A. Teixeira (1998) Mass transfer properties of glucose and $\mathrm{O}_{2}$ in Saccharomyces cerevisiae flocs. Biochem. Eng. J. 2: $35-43$.

[150] Vicente, A. A., M. Dluhý, and J. A. Teixeira (1997) A new technique for measuring kinetic and mass transfer parameters in flocs of Saccharomyces cerevisiae. Biotechnol. Tech. 11: 113-116.

[151] Vicente, A. A., M. Dluhý, E. C. Ferreira, and J. A., Teixeira (1998) Modelling diffusion-reaction phenomena in yeast flocs of Saccharomyces cerevisiae. Bioprocess Eng. 18: 335-342.

[152] Domingues, L., N. Lima, and J. A. Teixeira (2000) On the contamination of flocculating yeast high cell density continuous bioreactor. Biotechnol. Bioeng. 68: 584-587.

[153] Teixeira, J. A. and M. Mota (1992) Flocculation bioreactors. pp. 413-428. In: T. G. Villa and J. Abalde, (eds.) Profiles on Biotechnology. Servicio de Publicaciones, Universidade de Santiago, Spain. 
[154] Webster, I. A. (1981) Criteria for the prediction of diffusional control within whole cells and cell flocs. J. Chem. Tech. Biotechnol. 31: 178-182.

[155] Vicente, A. A., M. Dluhý, and J. A. Teixeira (1999) increase of ethanol productivity in an airlift reactor with a modified draught tube. Can. J. Chem. Eng. 77: 497-502.

[156] Greenshields, R. N. and E. L. Smith (1971) Tower-fermentation systems and their applications. Chem. Engineer May: 182-190.

[157] Smith, E. L. and R. N. Greenshields (1974) Tower-fermentation systems and their application to aerobic processes. Chem. Engineer January: 28-34.

[158] Linko, M., I. Virkajärvi, N. Pohjala, K. Lindborg, J. Kronlöf, and E. Pajunen (1997) main fermentation with immobilized yeast - a breakthrough?, Proceedings of EBC Congress 1997: 385-394.

[159] Masschelein, C. A. (1997) A realistic view on the role of research in the brewing industry today. J. Inst. Brew. 103: 103-113

[160] Mensour, N. A., A. Margaritis, C. L. Briens, H. Pilkington, and I. Russel (1997) New developments in the brewing industry using immobilized yeast cell bioreactor systems. J. Inst. Brew. 103: 363-370.

[161] Šmogrovicová, D., Z. Dömény, P. Gemeiner, A. Malovíková, and E. Šturdík (1997) Reactors for continuous primary beer fermentation using immobilized yeast. Biotechnol. Tech. 11: 261-264.

[162] Dömény, Z., D. Šmogrovicová, P. Gemeiner, E. Šturdík, J. Pátková, and A. Malovíková (1998) Continuous secondary fermentation using immobilized yeast. Biotechnol. Lett. 20: 1041-1045.

[163] Tata, M., P. Bower, S. Bromberg, D. Duncombe, J. Fehring, V. Lau, D. Ryder, and P. Stassi, (1999) Immobilized yeast bioreactor systems for continuous beer fermentation. Biotechnol. Prog. 15: 105-113.

[164] Kida, K., M. Yamadaki, S.-I. Asano, T. Nakata, and Y. Sonoda (1989) The effect of aeration on stability of continuous ethanol fermentation by a flocculating yeast. $J$. Ferment. Bioeng. 68: 107-111.
[165] Fontana, A., C. Ghommidh, J. P. Guiraud, and J. M. Na varro (1992) Continuous alcoholic fermentation of sucrose using flocculating yeast. The limits of invertase activity. Biotechnol. Lett. 14: 505-510.

[166] Kida, K., K. Kume, S. Morimura, and Y. Sonoda (1992) Repeated-batch fermentation process using a thermotolerant flocculating yeast constructed by protoplast fusion. J. Ferment. Bioeng. 47: 169-173.

[167] Kuriyama, H., H. Ishibashi, H. Miyagawa, H. Kobayashi, and M. Eiichi (1993) Optimization of two-stage continuous ethanol fermentation using flocculating yeast. Biotechnol. Lett. 15: 415-420.

[168] Wieczorek, A. and H. Michalski (1994) Continuous ethanol production by flocculating yeast in the fluidized bed bioreactor. FEMS Microbiol. Rev. 14: 69-74.

[169] Roca, E., C. Ghommidh, J. M. Navarro, and J. M. Lema (1995) Hydraulic model of a gas-lift bioreactor with flocculating yeast. Bioprocess Eng. 12: 269-272.

[170] Schorr-Galindo, S., C. Ghommidh, and J. P. Guiraud (1995) Inulin enrichment by fermentation in a flocculating yeast reactor. Biotechnol. Lett. 17: 1303-1310.

[171] Abate, C., D. Callieri, E. Rodríguez, and O. Garro (1996) ethanol production by a mixed culture of flocculent strains of Zymomonas mobilis and Saccharomyces sp. Appl. Microbiol. Biotechnol. 45: 580-583.

[172] Jianfeng, X., X. Jian, H. Aiming, F. Pusun, and S. Zhiguo (1998) Kinetic and technical studies on large-scale culture of Rhoiola sachalinensis compact callus aggregates with air-lift reactors. J. Chem. Technol. Biotechnol. 72: 227234.

[173] Mafra, I., J. M. M. Cruz, and J. A. Teixeira (1997) Beer maturation in a continuously operating bioreactor using a flocculation brewer's yeast strain. Proceedings of the EBC Congress 1997.

[174] Domingues, L., M. M. Dantas, J. A. Teixeira, and N. Lima (1999) Continuous cheese whey permeate alcoholic fermentation with a flocculent recombinant Saccharomyces cerevisiae. Curr. Genet. 35: 300.

[Received May 18, 2000; accepted August 8, 2000] 